\title{
QUEEN'S
UNIVERSITY
BELFAST
}

\section{Changing contours of employment in England and Wales between 1921 and 2011: Industry,occupation, gender and locality}

Penn, R. (2018). Changing contours of employment in England and Wales between 1921 and 2011:

Industry,occupation, gender and locality. Irish Journal Of Sociology, 26(3), 289-316.

https://doi.org/10.1177/0791603518805011

\section{Published in:}

Irish Journal Of Sociology

\section{Document Version:}

Peer reviewed version

Queen's University Belfast - Research Portal:

Link to publication record in Queen's University Belfast Research Portal

\section{Publisher rights}

(C) 2018 The Author(s).

This work is made available online in accordance with the publisher's policies. Please refer to any applicable terms of use of the publisher.

\section{General rights}

Copyright for the publications made accessible via the Queen's University Belfast Research Portal is retained by the author(s) and / or other copyright owners and it is a condition of accessing these publications that users recognise and abide by the legal requirements associated with these rights.

Take down policy

The Research Portal is Queen's institutional repository that provides access to Queen's research output. Every effort has been made to ensure that content in the Research Portal does not infringe any person's rights, or applicable UK laws. If you discover content in the Research Portal that you believe breaches copyright or violates any law, please contact openaccess@qub.ac.uk. 
Changing Contours of Employment in England and Wales between 1921 and 2011: Industry, Occupation, Gender and Locality

\title{
$\underline{\text { Roger Penn }}$
}

\begin{abstract}
The paper examines the contours of employment change in England and Wales between 1921 and 2011 using data from the respective Censuses of Population. The main focus of the analysis is the changes to industrial, occupational, gender and spatial patterns over the period.
\end{abstract}

Keywords: Structural change, industry, occupation, gender, locality. 
The central purpose of this paper is to provide an analysis of the changing structure of employment in England and Wales between 1921 and 2011. The focus is on four related sets of phenomena: changing patterns of employment across industrial sectors, changes to patterns of gender and paid employment, changes to occupational segregation by gender and the changing contours of locality differences within England and Wales. The core data have been taken from the respective Censuses of Population for England and Wales for 1921 and 2011. The analysis is restricted to England and Wales primarily because they form a single unit for census purposes. Further research is underway currently that will extend the research to Scotland and Ireland [both North and South].

\section{Census Data}

Census data come in three main forms. For the censuses taken during the nineteenth and early twentieth centuries, the original census returns completed by local enumerators are now available from 1841 until 1911. In addition, between 1801 and 1991, summary census data have been published in a series of volumes containing extensive tables. These are lodged physically at all the copyright libraries. . Recent census results from 2001 and 2011 have been disseminated online by the Office for National Statistics and are available in a variety of formats, including Excel files.

Originally I had hoped to compare data from the 1911 Census of Population with contemporary data as part of a wider assessment of the 'longue durée' of modern society. However, it became evident that the categorizations of industries and of occupations in 1921 was much clearer than those used in 1911 when 'occupation' and 'industry' had been conflated (see Szreter, 1984 and Nissel, 1985). This was the result of the primary aim of the original 1911 classification which mixed occupational status groups with industrial sectors to explore variations in mortality rates $\left(\right.$ Registrar General, 1913) ${ }^{1}$. The present analysis focused therefore on the 1921 data. This has been compared with equivalent data from 2011.

The 1921 Census is not available online and use was made of Cambridge University Library and to examine various volumes there [see Appendix A]. Census data in this form can be rather forbidding but they can be transformed into a tremendous resource for sociologists, particularly those concerned with social change [see Penn, 2014]. Historical census data offer a detailed picture of the social structure of Britain in the past and are indispensable for any kind of

\footnotetext{
${ }^{1}$ Registrar General (1911) Registrar General's Annual report, 1911 p.xli. London: HMSO.
} 
empirical assessment of the degree to which contemporary patterns differ from that past. However, census data are collected primarily for governmental and not for sociological reasons. In order to make use of such data it is crucial to reconfigure them in ways that both simplify them and simultaneously render them amenable to comparative analysis.

\section{Theoretical Departures}

A range of sociological theories concerning putative changes over the last century underpinned the research. The first was the notion of a 'gender revolution' across the western world since 1945 (see Blau, et al 2006, Berridge et al 2009, Cotter et al, 2011 and Razzu, 2014). This has been associated with a wide range of factors including the growth of feminism (see Evans, 2013), the impact of the contraceptive pill (see Watkins, 2001), increased levels of female educational attainment (see Arnot, David and Weiner, 1999) and, as a corollary, the expansion in the number of women employed in professional and managerial cadres (see Purcell \& Elias, 2008). These factors have been powerfully entwined with the 'second demographic transition' (see van de Kaa, 1987) which has witnessed decreasing rates of marriage and increasing rates of cohabitation (see Lesterhaeghe and Neels, 2002) as well as an increasing frequency of divorce (see Rees, 1997) plus an increasing proportion of childless women at the age of 40 (see McAllister and Clarke, 2001). Underpinning and interacting with all these changes has been an increase in female labour market participation, particularly in part-time employment (see Scott, Crompton and Lyonette, 2010).

The second sociological theory explored in the analysis was the notion of the emergence of a 'post-industrial' service economy since the 1920s. This is connected to human capital theory in economics and was strongly influenced by the arguments of the American labour economist, Fuchs (1968). He argued that the driving force of economic change in the twentieth century was technological innovation. The evolution of new advanced technologies - electronics in general and computerisation in particular - necessitated an increasingly educated workforce. Emphasis therefore was increasingly on investment in 'human' capital in the form of greater education and enhanced training. These ideas strongly underpinned subsequent sociological models of 'post-industrialism', notably those associated with Bell (1974) and Habermas (1976). This model strongly suggested two main inter-related processes of social change. The first was the increasing capital-intensity of manufacturing and the relative loss of aggregate employment in that sector. The other involved the massive parallel expansion of employment outside manufacturing within the diversified service sector. 
The third theory explored in the paper centres upon the notion popular amongst theorists of social stratification in Britain that a spatially concentrated male-dominated working class has progressively disappeared since 1945. The concept of a 'traditional' working class in Britain is powerfully associated with the work of two cultural historians: Raymond Williams (1958) and Richard Hoggart (1959). Both argued that close-knit working class communities were disappearing in post-war Britain as a result of increasing affluence and rehousing. The latter theme was also emphasised by Willmott and Young (1957). Very similar ideas were presented by Lockwood (1960 and 1966) on the putative nature of the 'new' working class and these fed into the subsequent seminal Affluent Worker series (see Goldthorpe et al 1969). Television programmes like Coronation Street and LS Lowry prints fed into this widespread nostalgia for a mythical past when a solidaristic working class was dominant.

These sociological theories were assessed using a long-term structural analysis influenced by the precepts of the French Annales School of social science (see Braudel, 1949 and Duby, 1973) which emphasised the need for a long-term focus for any sociological analysis of social change. Clearly such an approach is necessarily broad-stroke. Many details of changes within the overall period under scrutiny will perforce be lost. However, these disadvantages are more than compensated by the ability to see the wood from the trees within such a broad macro-style approach.

\section{Research Questions}

There were a series of empirical research questions that underpinned the research. The first centred upon the centrality of manufacturing industry and coal mining within the overall structure of employment in 1921. This point in time represented the high point of British economic dominance in world markets [see Clarke, 1996]. By 1931 the British economy was beset by the long Depression that cast such a pervasive shadow over British life throughout the 1930s [see Aldcroft, 1970 and Clavin, 2000]. In the decade before 1921 Britain had fought for four difficult years during the First World War and by its end manufacturing industry and coal mining were operating at peak intensity. A central purpose of the current analysis involved an assessment of the scale of manufacturing, mining and, pari passu, the size of those other sectors of employment which fell under the general rubric of 'services' in 1921. These patterns have been compared with the current era which has witnessed a significant decline in manufacturing employment as part of the growth of a 'post-industrial' service economy . 
A second theme of the analysis was to probe the changing relationship between gender and employment since 1921. Much contemporary sociology operates with an assumption that the post-1945 era has been transformed by a 'gender revolution' [see Blau, et. al. 2006]. This relates to a set of inter-related demographic, economic, cultural and social changes that are seen as premised upon a putative large increase in the proportion of adult women in paid employment outside the home [see Scott et al 2008]. The current analysis was designed to assess how accurate such assumptions are historically when compared to contemporary patterns of employment and to present an empirically-based benchmark against which more accurate historical comparisons can be made.

The analysis also focused upon occupational segregation by gender. This has been a longstanding feature of the British labour market (see Jarman et al, 2012). The research focused upon a limited range of occupations in order to probe the extent of horizontal segregation (see Blackburn et al, 2014) by gender between 1921 and 2011. Razzu and Singleton (2018) recently revealed that those currently working 'in personal services, administrative and clerical work, and sales and customer service work were far more likely to be women' [p3]. They also suggested that there continued to be considerable segregation by industry as well: 'men relatively outnumbered women in the public administration, education and health sectors' [p2]. The research explored the continuities and discontinuities in these patterns of gender segregation over the period.

The fourth purpose of the analysis involved an examination of the importance of specific industries to particular geographic locations. Sociologists (see Davis \& Cousins, 1975) and social commentators have long imagined a past world where one industry dominated employment in particular localities: cotton in the mill towns of Lancashire (see Savage, 1987), potteries in Stoke-on-Trent (see Whipp, 1990), coal in South Wales (see Beynon, 1985) and shipbuilding on the Clyde (see McGill, 1973 and Reid, 2010). This is seen as a dominant feature of 'traditional' British industrial society but to have progressively disappeared over the last 40 years (see Freeman, 1988 and Marsh \& Vogler, 1995). This trope will be explored in some detail in the subsequent analysis.

The four themes - industry, gender, occupational segreagation and place - underpin a great deal of taken-for-granted sociological discourse about societal change. The 1921 Census data were explored along each of these dimensions. Subsequently a parallel analysis of 2011 Census data was undertaken. However, an additional complication arose: in 1921 and 2011 there were separate Censuses of Population scheduled in the UK for England and Wales, Northern Ireland and for Scotland. In fact there was none completed for Northern Ireland in 1921 as a result of 
the conflict in Ireland at that time but separate censuses were undertaken for England and Wales and for Scotland. The present comparative analysis is restricted therefore to England and Wales. It requires significant further research to assess the situation in Scotland or in Ireland.

Industry and Occupation in the 1921 and 2011 Censuses

Both the 1921 and 2011 Censuses of Population presented tabular data on industry, occupation, gender and locality. The British Empire Statistical Conference in London in 1920 (see Coats, 1920) resolved to separate occupation and industry which had been conflated earlier in the 1911 classification of occupations (see Census of England and Wales, 1921 General Report, 1927). The Conference stated that 'the basic principle of the industrial classification should be the product or type of service and that of the occupational classification the process carried out, and the material worked in'. As a result two separate volumes were published based upon the 1921 Census: one as Occupational Tables (1924) and the other as Industry Tables (1925). These two volumes formed the cornerstone of the paper as far as data for 1921 were concerned (see Appendix A for the precise tables used). The data for 2011 (see Appendix A) were taken from data provided online at the ONS webpage [https://www.nomisweb.co.uk].The data on industry were based upon information provided on respondents' main job and were based upon the main activity of their employer or business. These were then coded into the 2007 Standard Industrial Classification (ONS, 2009). Occupational data were based upon a person's main job and were derived from their job title or details of the activities involved in their job. These was then assigned to an occupational code based upon the 2010 Standard Occupational Classification (ONS 2010a; ONS 2010b).

Gender featured in both censuses and was based upon self-identification as either male or female. Place was also extracted from both Censuses in 1921 and 2011. The localities identified for 1921 were primarily County Boroughs whilst those in 2011 were the modern administrative units for the same locations. In all cases used in this analysis they differed by only a small degree in terms of areas covered.

The 1921 Census tables on industries, gender, place and occupations are both complex - and on first reading - quite daunting. It was necessary initially to extract key information into tabular form. [These original tables are listed in Appendix A] This involved transcribing 
elements of the original table into a new table that could be entered into the software package Excel. The 2011 data conveniently came in an Excel format and could be transformed there directly [see Appendix A for the specific Excel speadsheets used] Thecentral aim of the subsequent analyses was to reconfigure these data into comparable categories wherever feasible. The basis for the industrial classifications used in the comparison of 1921 and 2011 are presented in Appendix B. These involved reclassifying the original categorizations into a form that was amenable to comparison. This was generally practicable. For example the 'Education' and 'Health' sectors used in 2011 were compared with two newly created sectors with the same names in 1921 through the reclassification outlined. However, the two sectors 'Commerce' in 1921 and 'Retail and Wholesale' in 2011 were perhaps the most difficult to compare precisely.

\section{Sectoral Patterns of Employment in 1921}

It is clear from Chart A that sectoral employment in England and Wales in 1921 was dominated by manufacturing industry. Overall 6.0 million were employed in manufacturing out of a total workforce of 17.6 million. Engineering accounted for 2.2 million and 1.2 million were

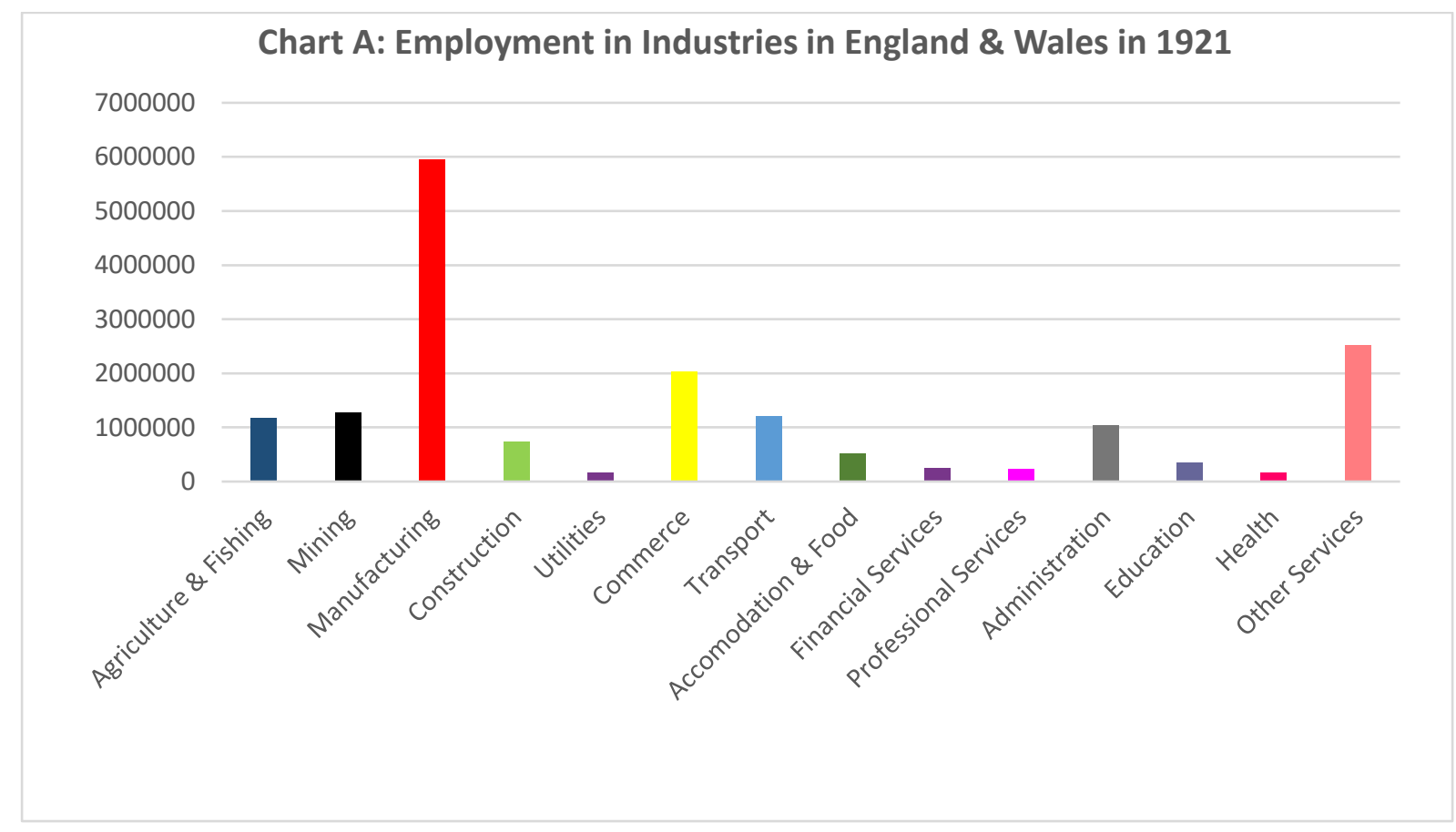


employed in textiles. Coal mining was also a major area of employment with 1.1 million miners employed (see Church, 1986) as was agriculture and fishing (1.2 million). Nonetheless, it is also apparent that the workforce in 1921 was by no means exclusively concentrated in mining, manufacturing and agriculture and fishing. These three sectors accounted for $48 \%$ of total employment. There was also a diverse pattern of employment across the service sector. There were large numbers employed in commerce (2.0 million), transport (1.2 million), administration (1.0 million) and construction (0.7 million). Education and health combined, on the other hand, only accounted for 524,083 at this time.

\section{Gender and Employment in 1921}

Only a third of females were economically active in 1921 compared to around $85 \%$ of males. This indicated that the increase in female economic activity associated with the First World War [Grayzel, 1999 and Braybon, 2012] had been but a temporary phenomenon and had been quickly reversed after the end of hostilities. Nonetheless, there remained a significant female workforce in 1921. The notion of exclusively male bread-winners in 1921 (see Seccombe, 1986 and Crompton, 1999) ignores the presence of 5,065,332 female workers at this time and is well off the historical mark (see Lewis, 1984 and Roberts, 1988).

It is also evident that there were significant differences between the pattern of male and female employment in 1921 [see Chart B]. Mining was almost exclusively male. This was mainly a consequence of the 1842 Mines Act which had prohibited female employment underground. Transport, construction, agriculture, administration and utilities were also predominantly male. $68.0 \%$ of manufacturing workers were male, although in absolute terms there were also a large number of women also employed in the sector [1.7 million]. Health, education and professional services employed greater proportions of women than men at this time. 
Chart B: Industry by Gender in England \& Wales in 1921

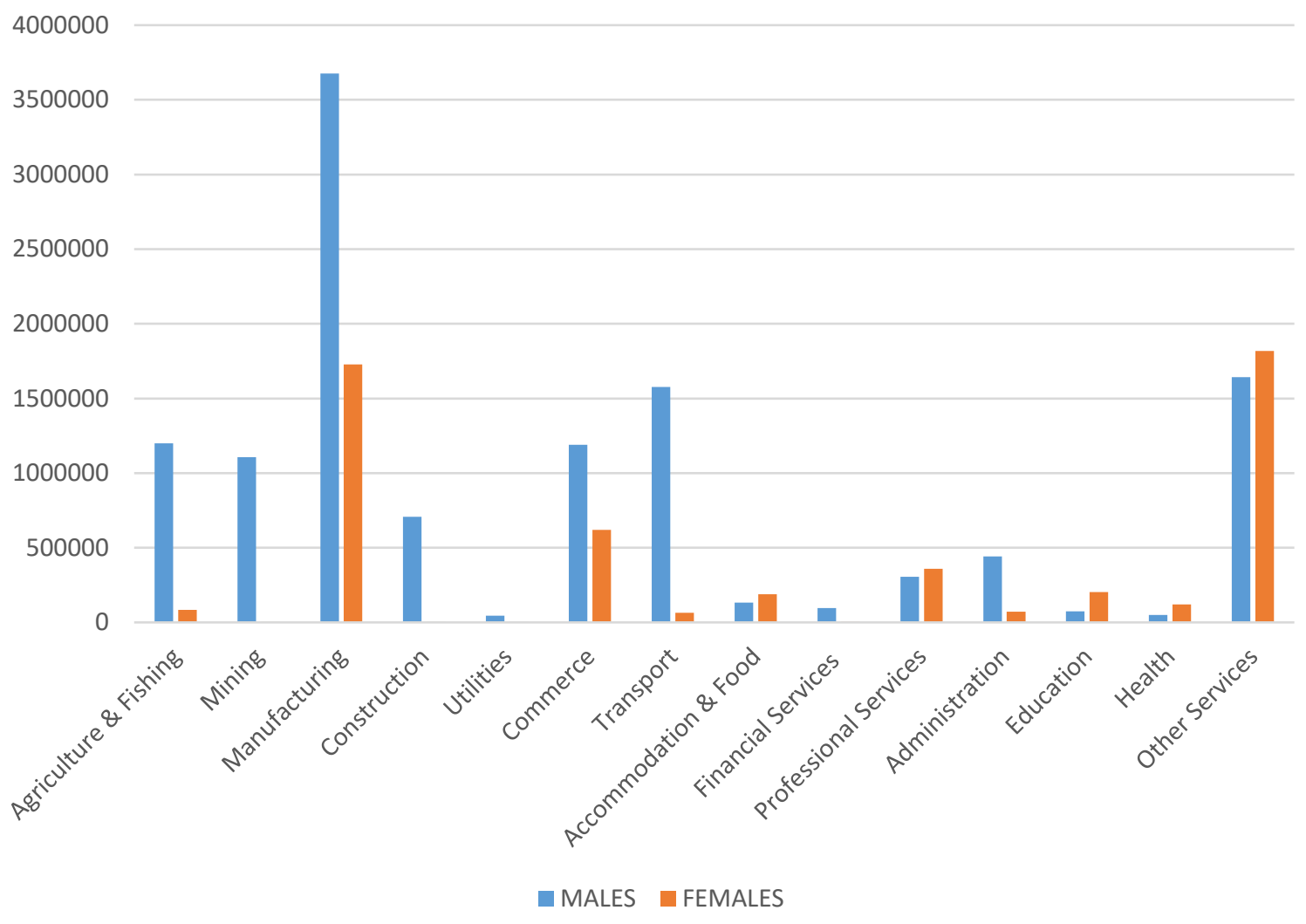

\section{Occupational Segregation by Gender}

However, it is also evident [see Charts C and D] that there were large variations between subgroups within both manufacturing and services in terms of the gender profile to employment. Coal mining was almost entirely male, as were occupations in transport and construction. 


\section{Chart C: Number of Males \& Females in Selected Industrial Sectors in England \& Wales in 1921}

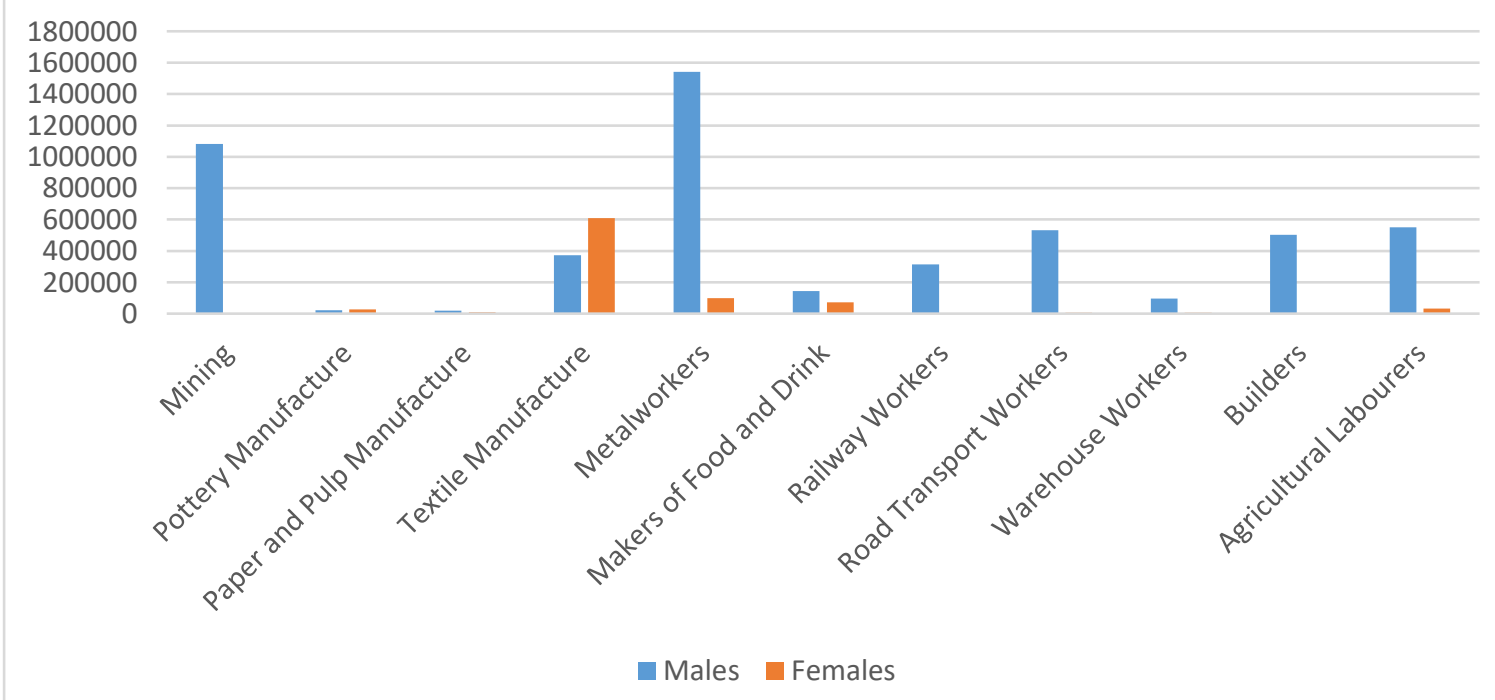

Most sectors within manufacturing were also predominantly male, with the notable exceptions of textiles, clothing and pottery [see Chart C]. Female employment was far more pronounced in the service sector. Most teachers and domestic servants and almost all nurses were female (see Roberts, 1988). There were also large numbers of women employed as shop assistants and clerks [see Chart D].

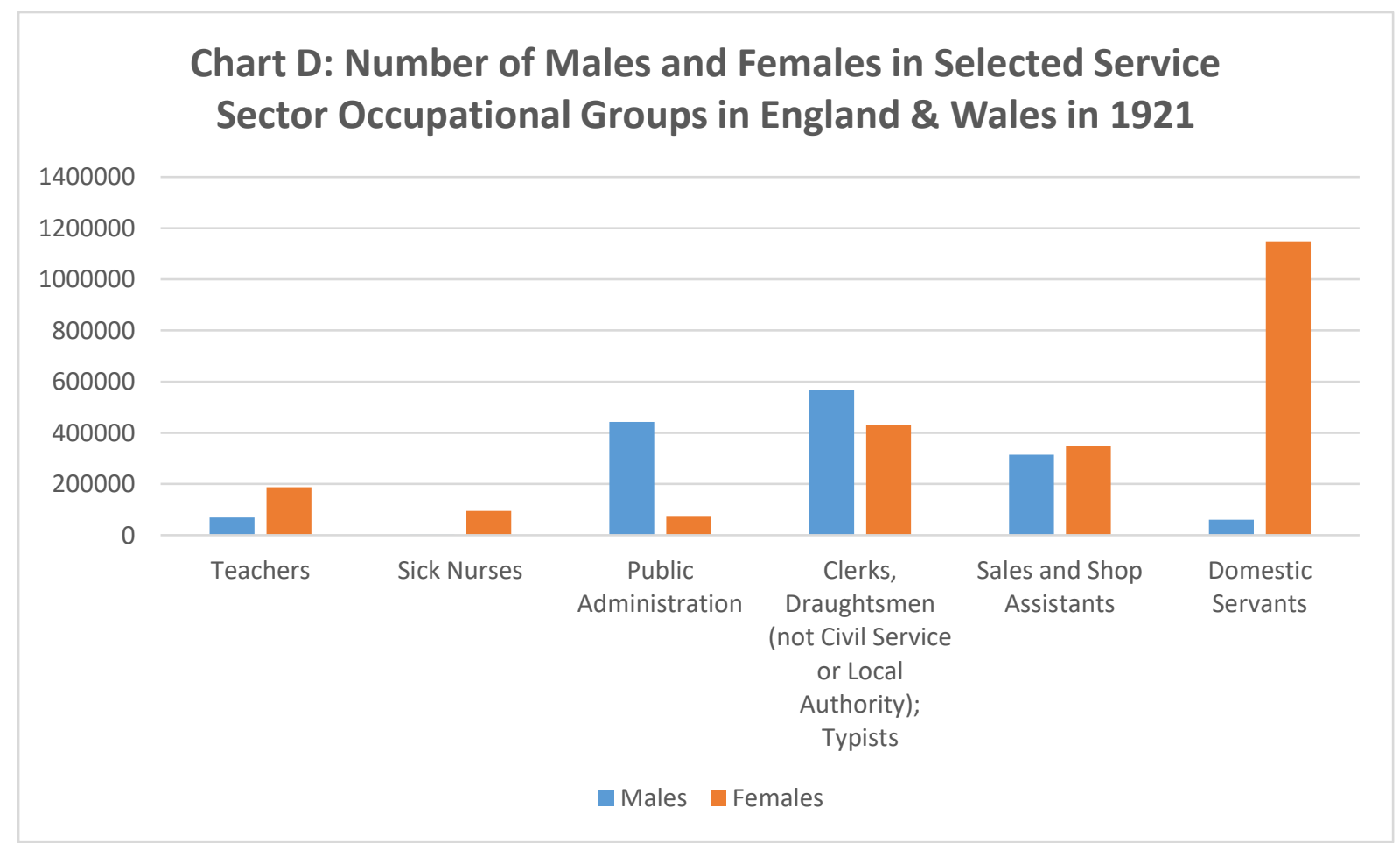


The wide variation in the proportion of women employed in various occupational groups is shown clearly in Chart E. As has been outlined above, almost all domestic servants were female in 1921. The Census reported that there were 1,148,698 female servants and only 61,006 males. This archetypical nineteenth century Victorian female occupation still had considerable purchase upon the social, economic and cultural life in inter-war England and Wales [see Lethbridge, 2013]. ${ }^{2}$. At the other end of the spectrum there were 1,081,749 men employed in coal mining [525,031 of whom 'got' the coal at the coalface using picks and shovels $\left.{ }^{3}\right]$ and a mere 3334 women. Between these two extremes, some occupational groups were predominantly male [transport, construction and agricultural workers] whilst others were much closer to gender parity such as clerical workers and shop assistants.

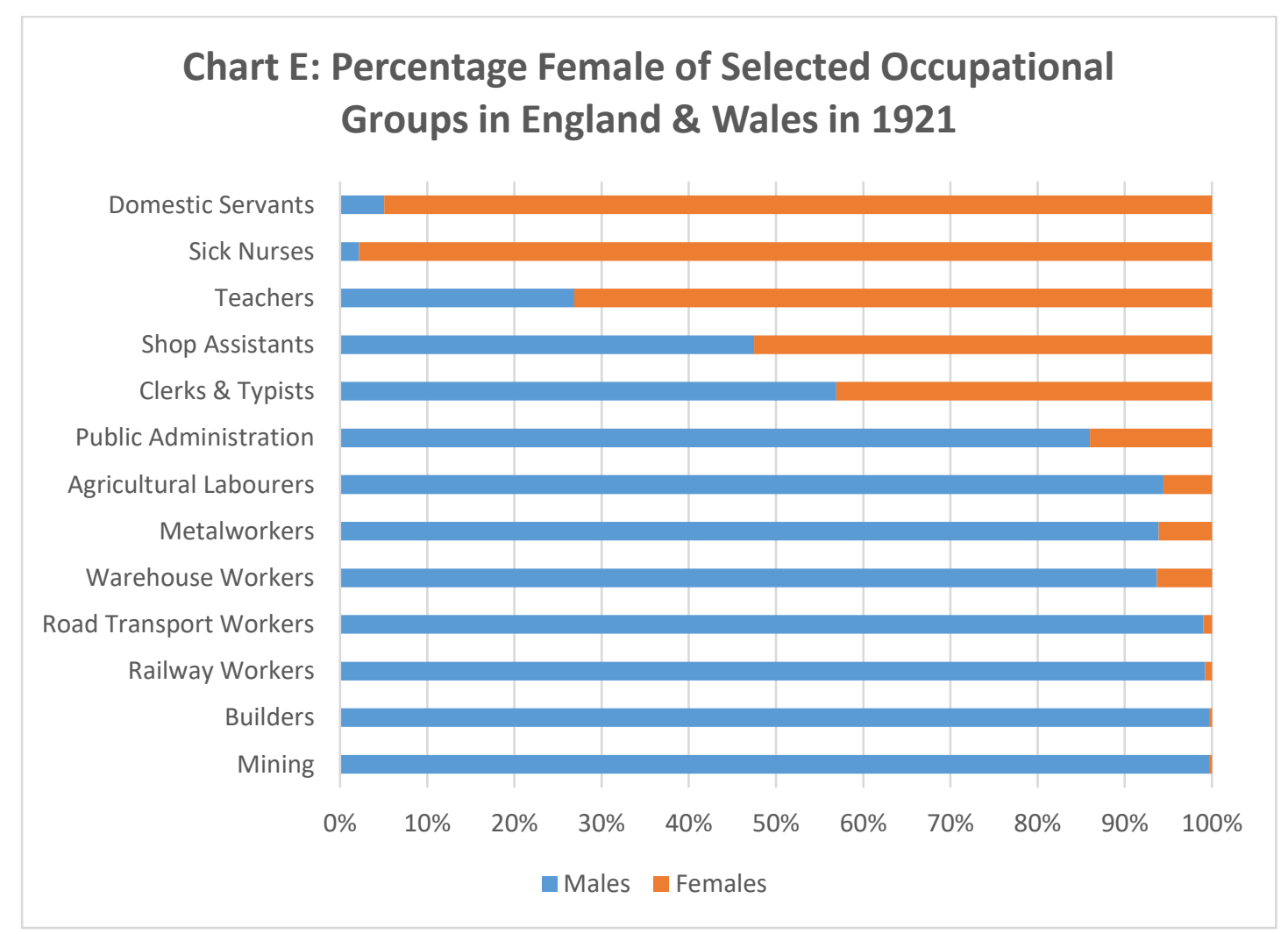

Skilled manual work in Britain throughout the nineteenth century had been traditionally male (see More, 1980). In Britain, the craft unions that represented skilled workers in the later nineteenth century explicitly excluded women from membership (Walby, 1986). The Amalgamated Society of Engineers did not permit women's membership of their craft union until 1943 and they strongly opposed the presence of women in craft areas of metalworking

\footnotetext{
${ }^{2}$ This has been portrayed recently in the highly popular television series, Downton Abbey

${ }^{3}$ See Ashworth (1986)
} 
[dilution] during the First World War (Cole, 1923a and 1923b). At the end of hostilities traditional restrictions on the employment of women in skilled trades were swiftly re-imposed (Penn, 1985). In many areas of skilled work, trade unions, or more precisely trade unionists, had a powerful voice in the selection of apprentices. In the cotton industry, the loom overlookers (maintenance and supervisory workers in the weaving sheds) voted on the desirability of potential recruits for apprenticeships in a manner identical to the 'black-balling' used by exclusive patrician organisations like London clubs. In printing, the compositors had the effective right of veto over applicants for apprenticeships, and there was a long-standing general tradition of 'speaking for' young lads by older male skilled workers, particularly by their fathers and uncles (see Penn, 1997).

It is apparent from Chart $\mathrm{F}$ that skilled manual occupations remained overwhelmingly male in 1921. Skilled trades in metalworking, construction and textiles revealed patterns of almost complete male domination at this time. The traditional patterns of male exclusivity had been re-imposed completely after the ending of temporary dilution during the First World War.

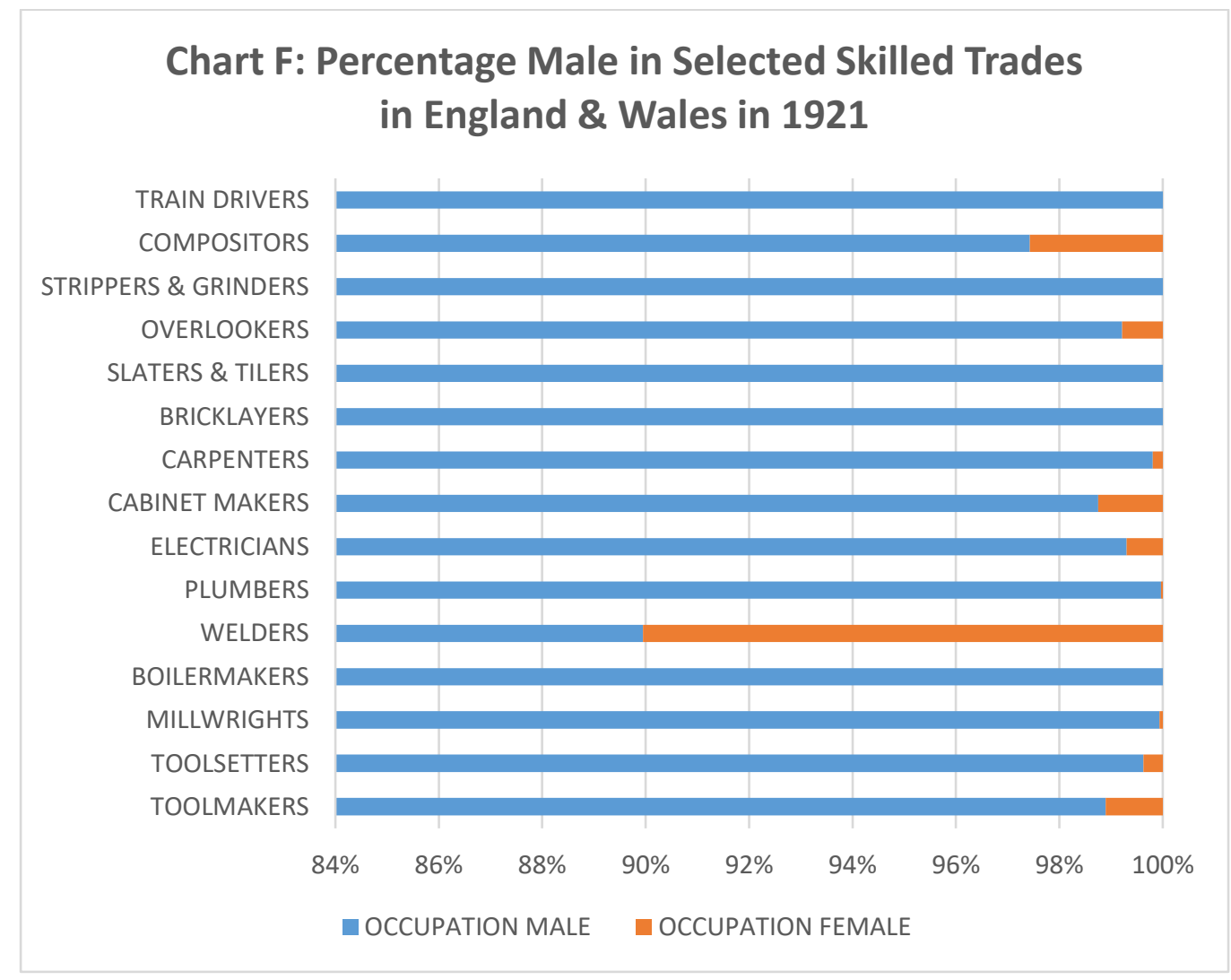




\section{Locality Variations in 1921}

It is apparent from Chart $G$ that the number of women employed in the coal industry was extremely small. Female employees represented around half a percentage point overall. Indeed, the proportion of females in the four main areas where the coal industry was mainly concentrated in England and Wales - Lancashire, Yorkshire, the North East and South Wales - was so small as to be almost invisible on the clustered bar charts. This male dominance in coal employment paralleled the overall preponderance of men within overall patterns of employment within the main coal producing areas themselves. However, there were also marked differences between the four coal fields. In Lancashire and Yorkshire patterns of employment were significantly less male dominated, reflecting the presence of large numbers of women employed in textiles in both areas. South Wales, and to a lesser extent, the North East were far more male dominated areas of employment. This was largely a function of the size and dominance of coal mining itself within the overall structure of employment in these two areas [see Graph H]. In the largest coal field - South Wales - mining accounted for fully $40 \%$ of total employment whereas in Lancashire it amounted to only $5 \%$.

\section{Chart G: Numbers of Males \& Females Employed in Coal Mining Areas of England \& Wales in 1921}

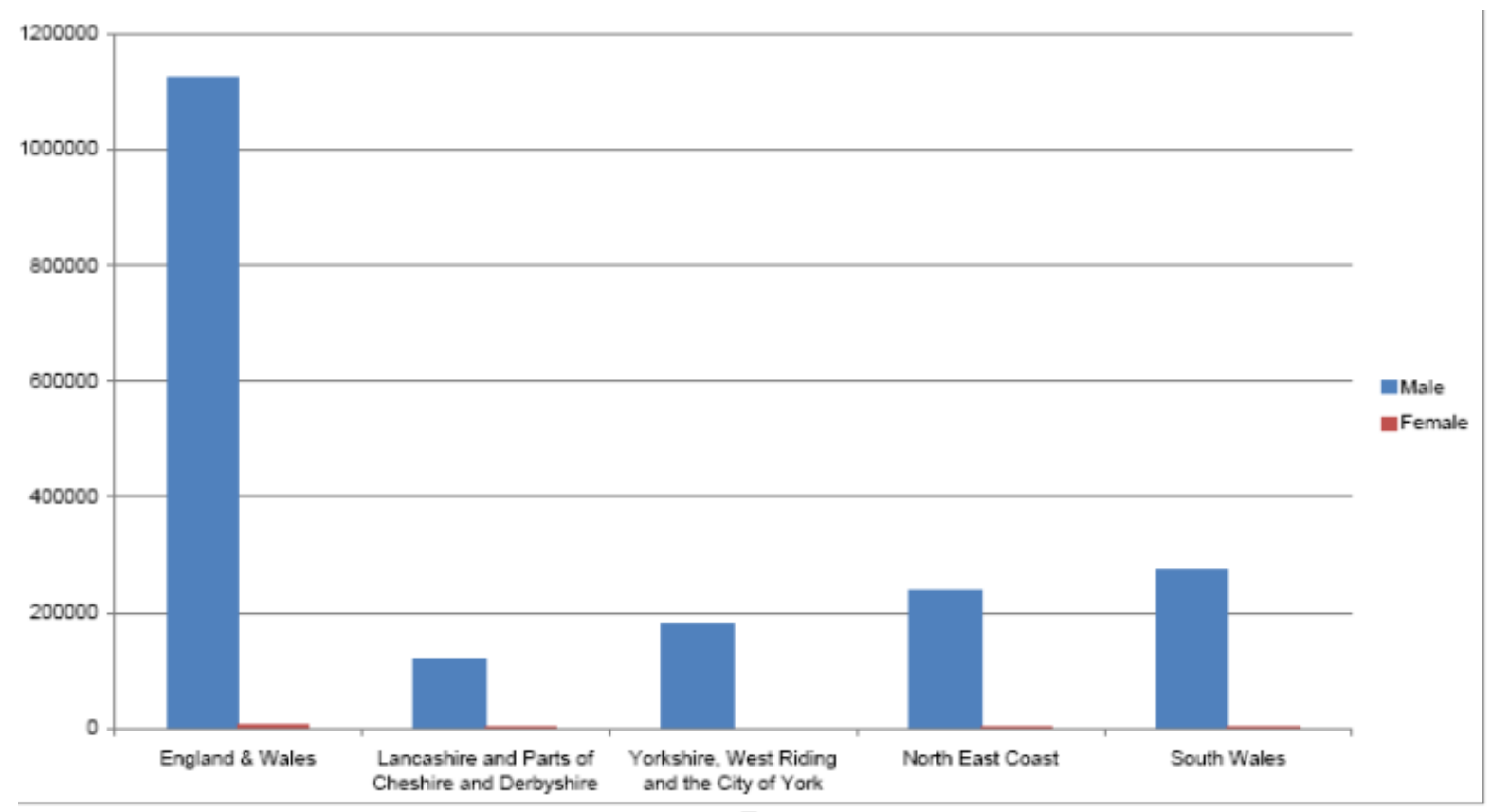


Chart H: Proportion of the Workforce Engaged in Coal Mining in Areas of England \& Wales in 1921

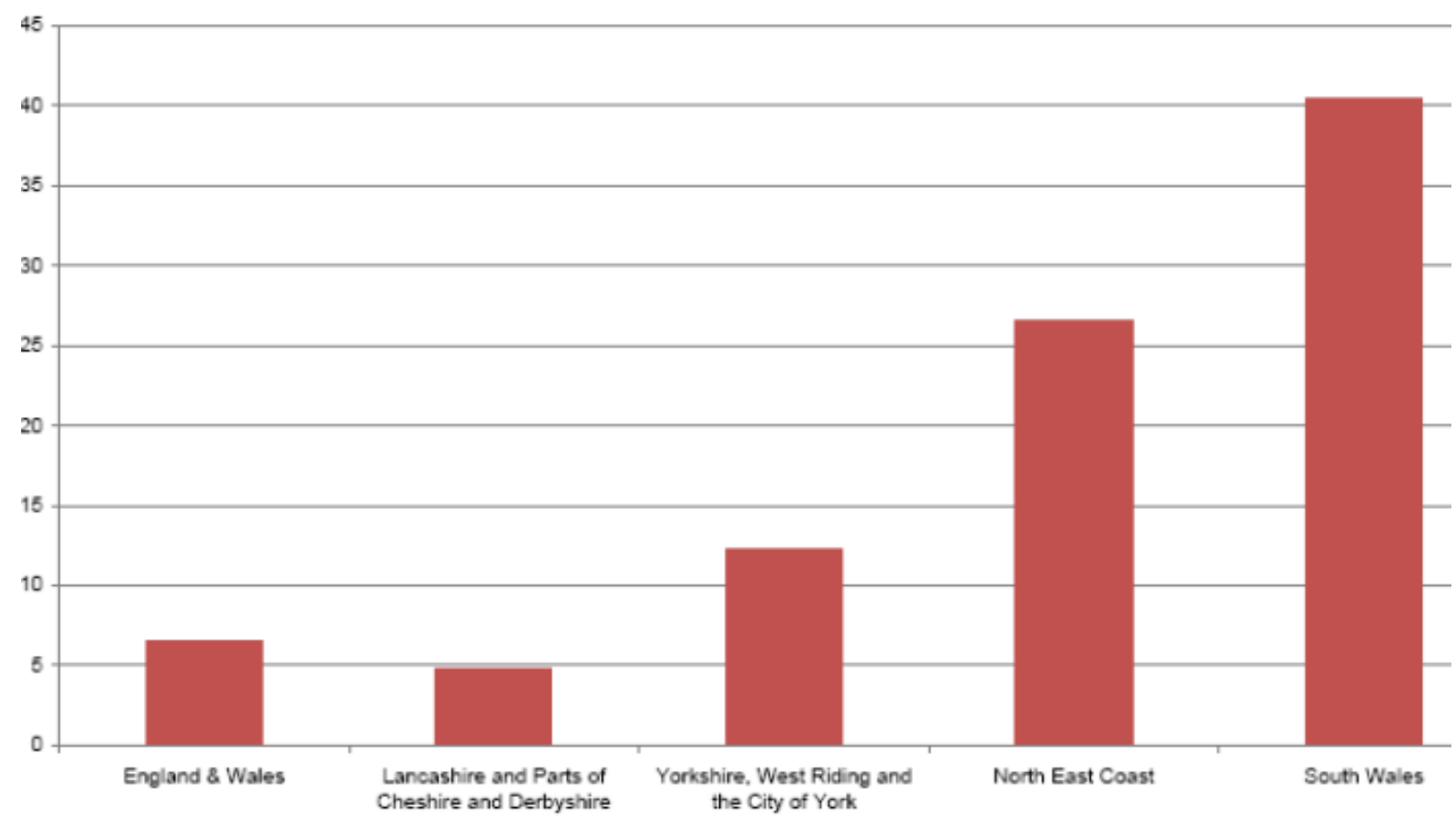

The engineering industry [excluding marine and electrical engineering] employed 2.2 million people in England and Wales in 1921. This comprised $12.5 \%$ of the entire workforce. However, certain localities were far more dominated by engineering than others. Almost $17 \%$ of the adult population of Swindon was employed in engineering [Chart I]. This reflected the impact of the Great Western Railway upon manufacturing in the town where its locomotive works employed over 14,000 people [see Cattell \& Falconer, 1995, p.181]. Derby and Newcastle-upon-Tyne were also localities where engineering workers accounted for almost $5 \%$ of the total population. There were also considerable variations in the proportion of females employed within engineering across these localities. In Birmingham around one in seven engineering workers were women whilst in Derby it was less than one in fifty [see Chart J]. Similar variations were evident in the shipbuilding industry which employed 283,443 people in 1921. Barrow - home to Vickers at that time - was heavily dominated by its shipyard [see Trebilcock, 1977 and Evans 1978]. Over a fifth of the entire adult population of Barrow was employed in the shipbuilding industry [see Graph K]. In Newcastle - another great shipbuilding city - around 5\% of the adult population was engaged in building ships. This 
lower proportion than Barrow reflected the greater mix of employment in Newcastle which also included engineering and coal mining.
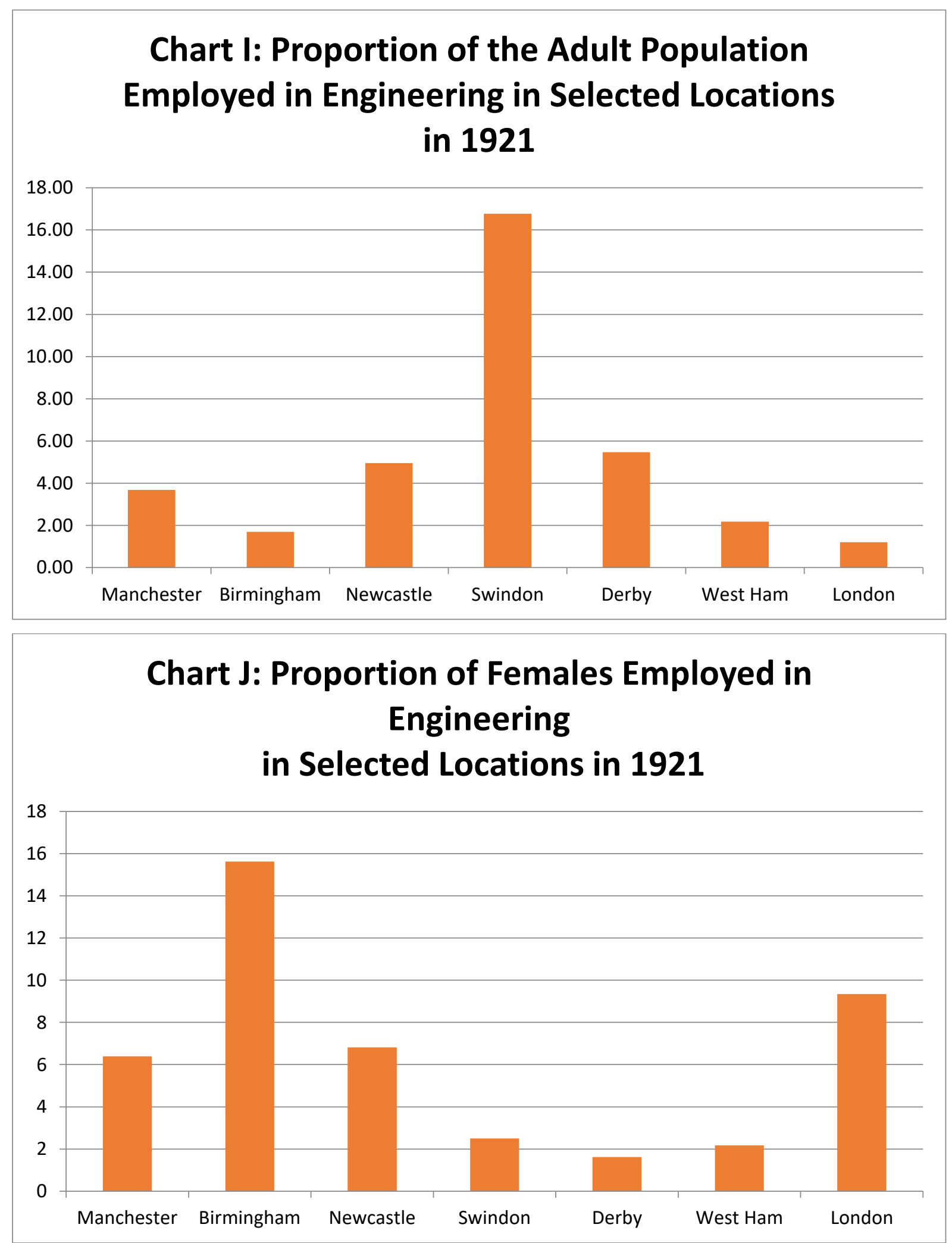

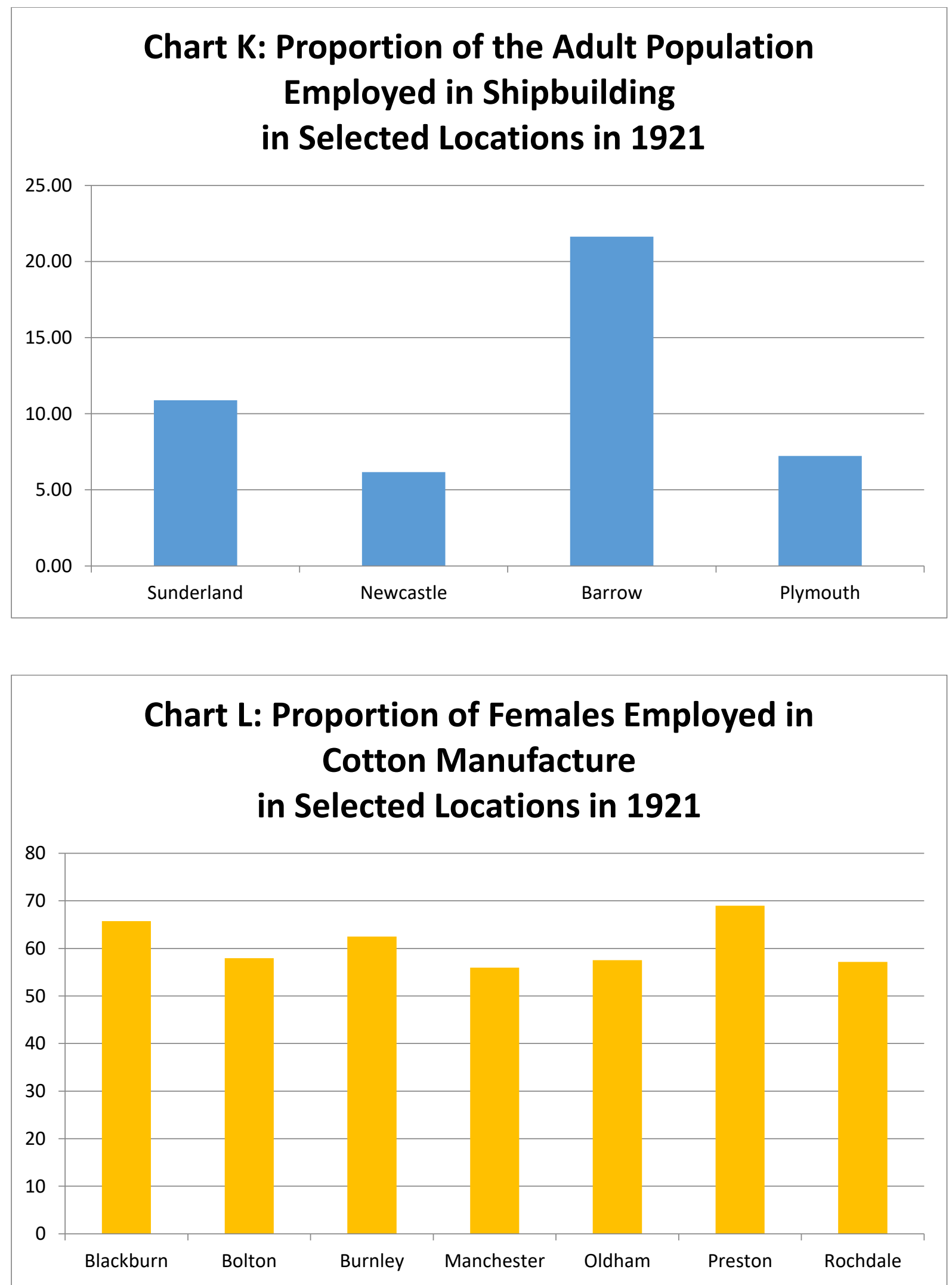

The cotton industry based in Lancashire revealed a dramatically different profile to employment when compared to engineering. In all seven localities highlighted, the proportion 
of cotton workers who were female was over half [see Chart L]. In the weaving towns of Preston females accounted for $69.0 \%$ and in Blackburn $65.7 \%$ of the total workforce. In the spinning towns further south, the proportion of women workers in cotton was $57.2 \%$ in Rochdale and $57.5 \%$ in Oldham.

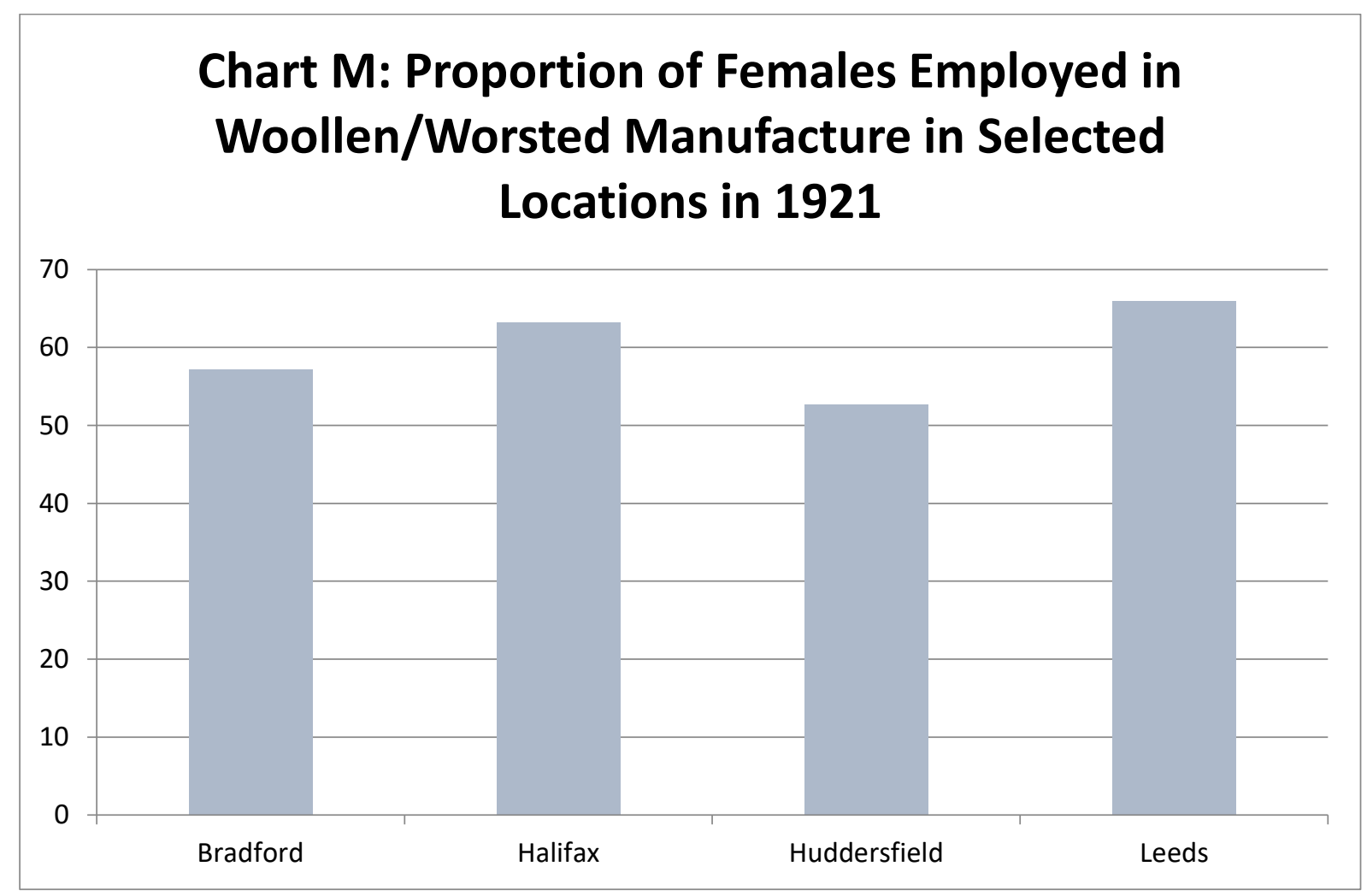

Similar patterns were evident in the woollen and worsted industries in the West Riding of Yorkshire [see Chart M]. In the four localities examined - Bradford, Halifax, Huddersfield and Leeds - over $50 \%$ of the workforce employed in woollen and worsted were women.

The spatial concentration of textile manufacturing in Lancashire [cotton] and West Yorkshire [woollens] meant that these areas had a very different structure to employment from overall national averages. In the Lancashire cotton towns and in the woollen areas of the West Riding both adult men and adult women were engaged in paid employment. This had a series of distinctive social, economic and cultural effects upon these localities. Household incomes were relatively high amongst manual working class families, particularly those containing male skilled workers [see Penn, 1985]. This underpinned high levels of home ownership ${ }^{4}$ and high expenditure on leisure activities such as watching professional sport [see Walvin, 1994] and going on holiday, most notably to Blackpool [Walton, 2000]. High household incomes also

\footnotetext{
${ }^{4}$ Many of the original building societies had their origins there.
} 
supported the growth in the consumption of fast food, especially fish and chips [see Walton, 1992]. These regional patterns pre-dated the general national transformation of employment in Britain after the Second World War when women in general increasingly entered the labour market. They also provide evidence of a 'proto-McDonaldization' of family life fully 70 years before the concept was popularized by contemporary sociologists [See Ritzer, 1993].

\section{Sectoral Employment in 2011}

Employment patterns across industries in 2011 show significant changes when compared with 1921. The most dramatic change has been the virtual disappearance of coal mining. In 1921 there were 1.1 million employed in mining but by 2011 this had declined to 47,007 . Various factors underpinned this change. The shift in electricity generation from coal to gas and nuclear energy, coupled with the increasing importation of cheaper overseas coal after 1985 signalled the death knell of British coal production. This was intensified by the growth of renewable sources of electricity generation such as wind turbines and solar panels. The de-coupling of coal, energy and steel manufacture once they had been de-nationalized also acted to weaken the centrality of coal production within the overall British economy. In 1921, almost one in ten male workers worked in coal mining. Nowadays it is less than one in five hundred.

Another major change has been the decline in manufacturing employment [see Newell, 2007]. In 1921, there were almost 6 million employed in manufacturing but by 2011 this had fallen to 2.4 million. The proportion of the workforce employed in manufacturing shrank from $33.9 \%$ in 1921 to $8.3 \%$ by 2011 . The reasons for this are complex. They include the shift of relatively low-skilled labour-intensive jobs such as textiles and clothing from Britain [and other advanced economies like the USA] to less developed economies [see Schulman, Leiter \& Zingraff, 1991]. This is coupled with increasing capital intensity in industries like papermaking [see Kristensen \& Lilja 2012] and aerospace [see Danford et al, 2005] which continue to thrive in Britain. Fewer workers are needed in those advanced factories that continue to operate in Britain [see Jones, 1997 and Fingleton, 1999].

The obverse of this decline in mining and manufacturing has been the massive expansion of employment in the service sector since 1921. Employment in retail and wholesale [categorized as 'commerce' in 1921] increased significantly from 2.0 million [11.5\%] in 1921 to 4.2 million [16.1\%] by 2011 [see Chart N]. Britain is indeed a nation of shoppers! The increased affluence brought about by increasing productivity and overall economic growth has underpinned the growth of supermarkets [see Akehurst \& Alexander, 1996] to sell consumer goods and of 
wholesaling to supply these retail outlets. This process has also driven the growth of employment in transport as part of the wider logistics revolution [seeBonacich \& Wilson, 2008 and Fernie \& Sparks, L. 2014 ].

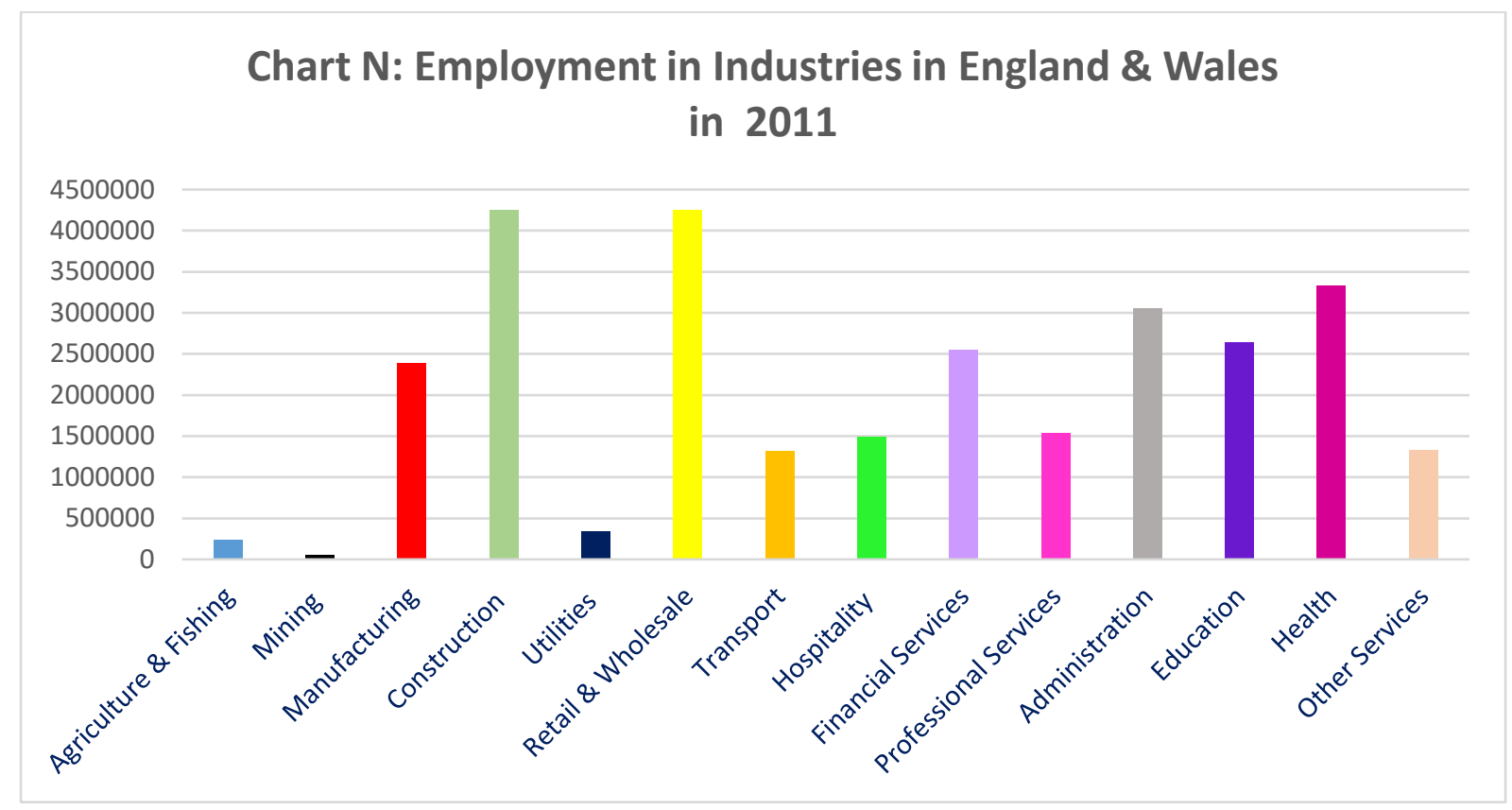

Employment in education and health has also grown significantly. In 1921 the school leaving age was 14 and the overall number of students in higher education was very small. In 1922 only 10,800 degrees were awarded in the UK [see Bolton, 2012]. Even in the 1950s primary school classes were routinely over 70 and university enrolments only began to expand significantly in the 1960s. Nowadays $48 \%$ of 18 year olds in England and Wales continue into higher education and the school leaving age has risen to 18 [see Universities UK, 2015 and Department of Education, 2016]. Employment in education has risen from 353,503 in 1921 to 2.6 million in 2011. The growth of employment in healthcare has been even greater than in education. In 1921 there were 170,580 employed in healthcare, but by 2011 this had burgeoned to 3.3 million. Indeed, the National Health Service had become the largest employer in Europe with 1.7 million employees.

There has also been a large growth of employment in financial and professional services. As the economy has become more complex and as overall affluence has increased, the provision of general financial and professional services has expanded enormously. In addition, the City of London itself employed 454,700 people in 2016 and generated around 22\% of total GNP in the UK [Oxford Economics, 2012 and Office for National Statistics, Statistical Bulletin, 2016]. 


\section{Gender and Employment in 2011}

Economic activity rates converged between males and females between 1921 and 2011. In $192185 \%$ of males were economically active but by 2011 this had fallen to $75 \%$. Female economic activity rates have risen from around a third in 1921 to almost two thirds by 2011 [see Razzu \& Singleton, 2018]. As Connolly and Gregory (2007) have argued, the growth of female employment in Britain has been 'one of the most sustained and significant economic trends of the second half of the twentieth century' [p142]. Various factors have led to these changes. Male economic activity rates have fallen partly because of increases in unemployment and also in long term ill health. In addition, increasing levels of early retirement amongst men have affected this trend. Female economic activity rates have been affected by the enormous growth of part-time flexible patterns of employment (see Dex et al, 2008), particularly in sectors like retailing (see Akehurst \& Alexander, 1996nand Farnie \& Sparks, 2014). Part of the overall change is also accounted for by increasing competition between males and females in the labour market, particularly amongst workers with relatively high educational qualifications and credentials.

Nonetheless, despite these structural changes, the overall gender profile to sectoral patterns of employment in 2011 remained remarkably similar to that in 1921 [see Chart O]. In education, $71.5 \%$ of employees were female in 2011 compared to $70.0 \%$ in 1921 . Healthcare revealed a similar pattern: $78.0 \%$ of healthcare employees were female in 2011 compared to $71.0 \%$ in 1921. Indeed, there had been a slight intensification in the gender imbalance over the period under review in both sectors of employment. Patterns of employment in construction and transport remained predominantly male as did manufacturing in 2011. Retail and wholesale appeared balanced in 2011 in terms of its overall gender profile but this masked powerful gender differences between the two main constituent elements: $67.8 \%$ of retail sales assistants were female whilst $84.1 \%$ of warehouse workers and $97.7 \%$ of forklift truck drivers [who are concentrated in warehousing] were male. Overall retail employment is predominantly female, whilst employment in wholesale remains mainly the preserve of male workers 


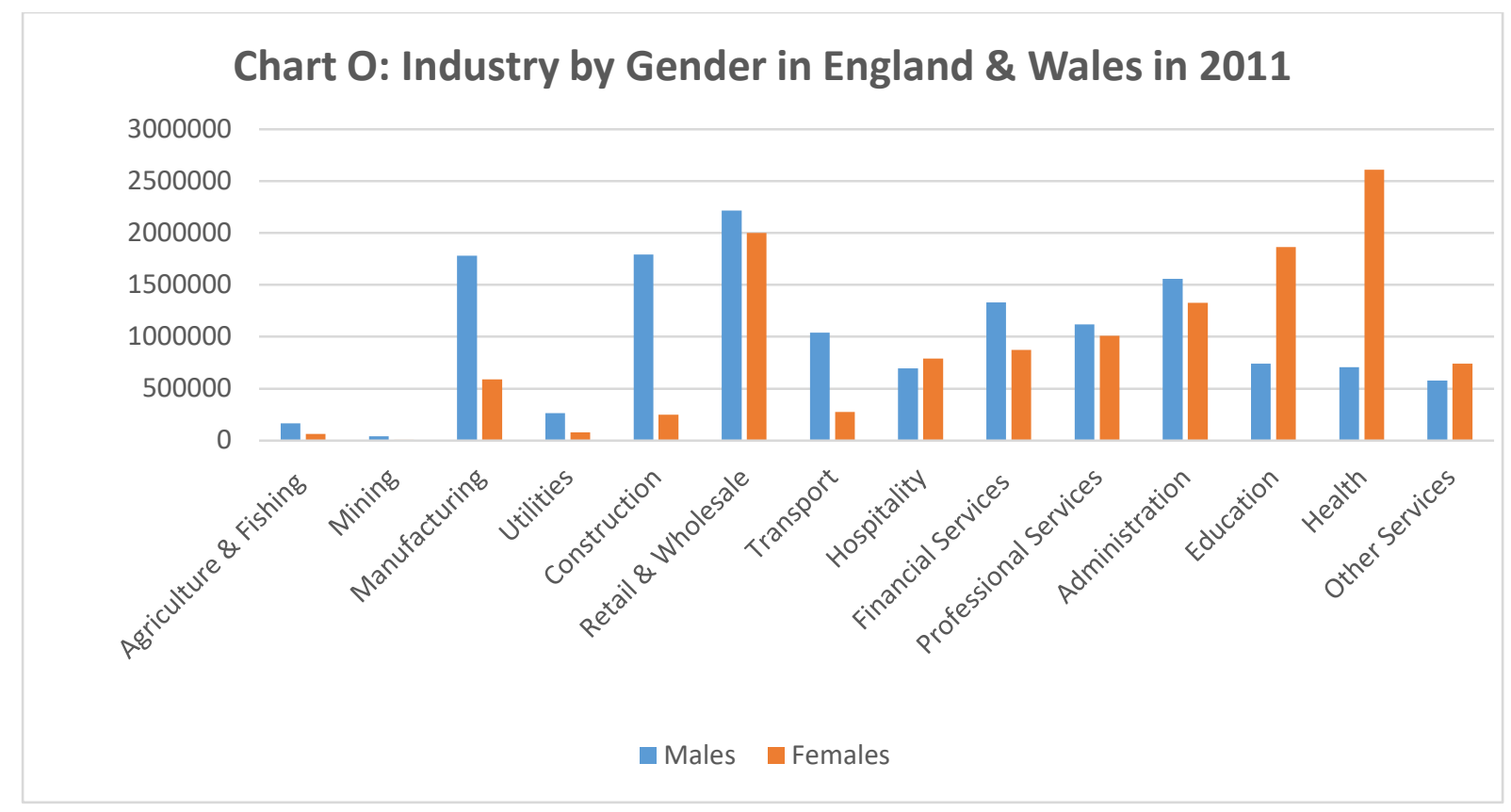

\section{Occupational Segregation in 2011}

It is interesting to note [see Chart P] that the gendering of employment patterns within education has an element of additional structuration. Teachers in secondary schools are much likelier to be male than those in primary schools. The lowest status occupation involved in teaching - teaching assistant - is even more female-dominated.

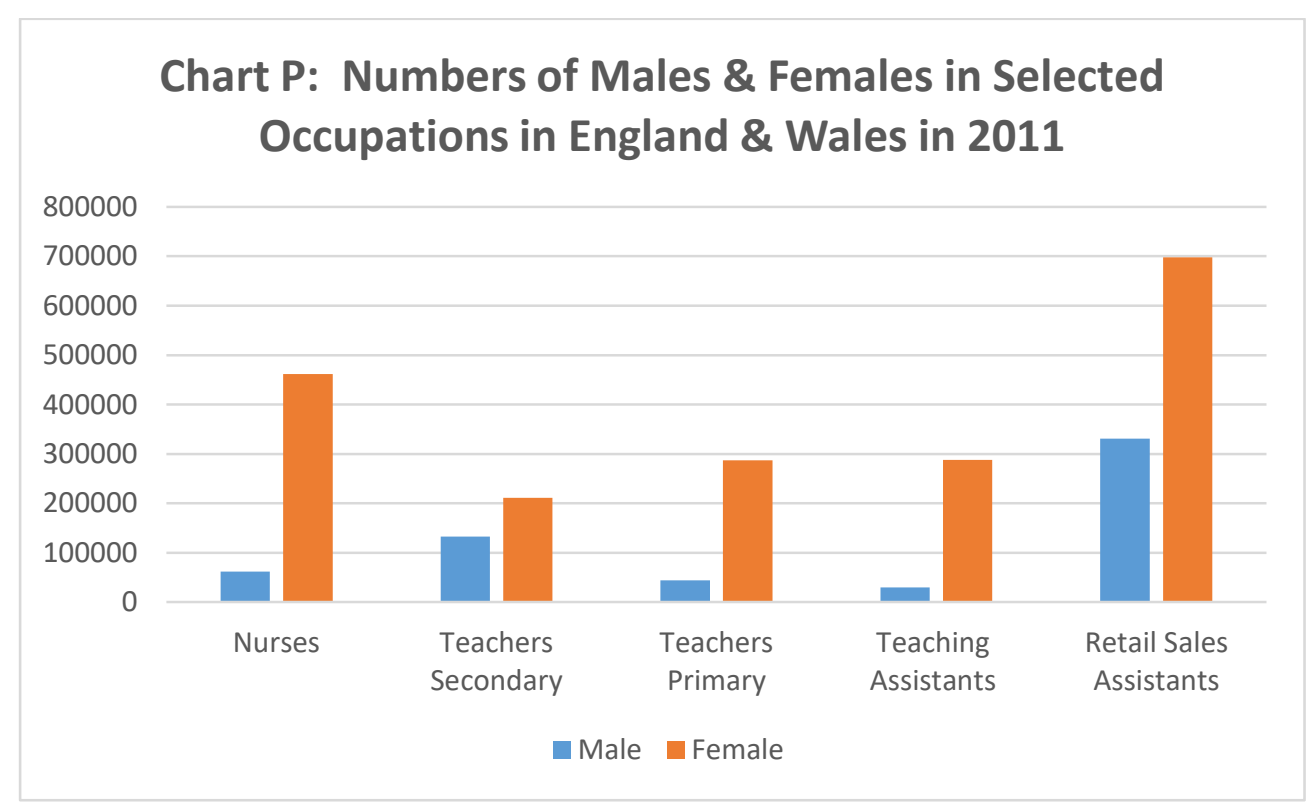




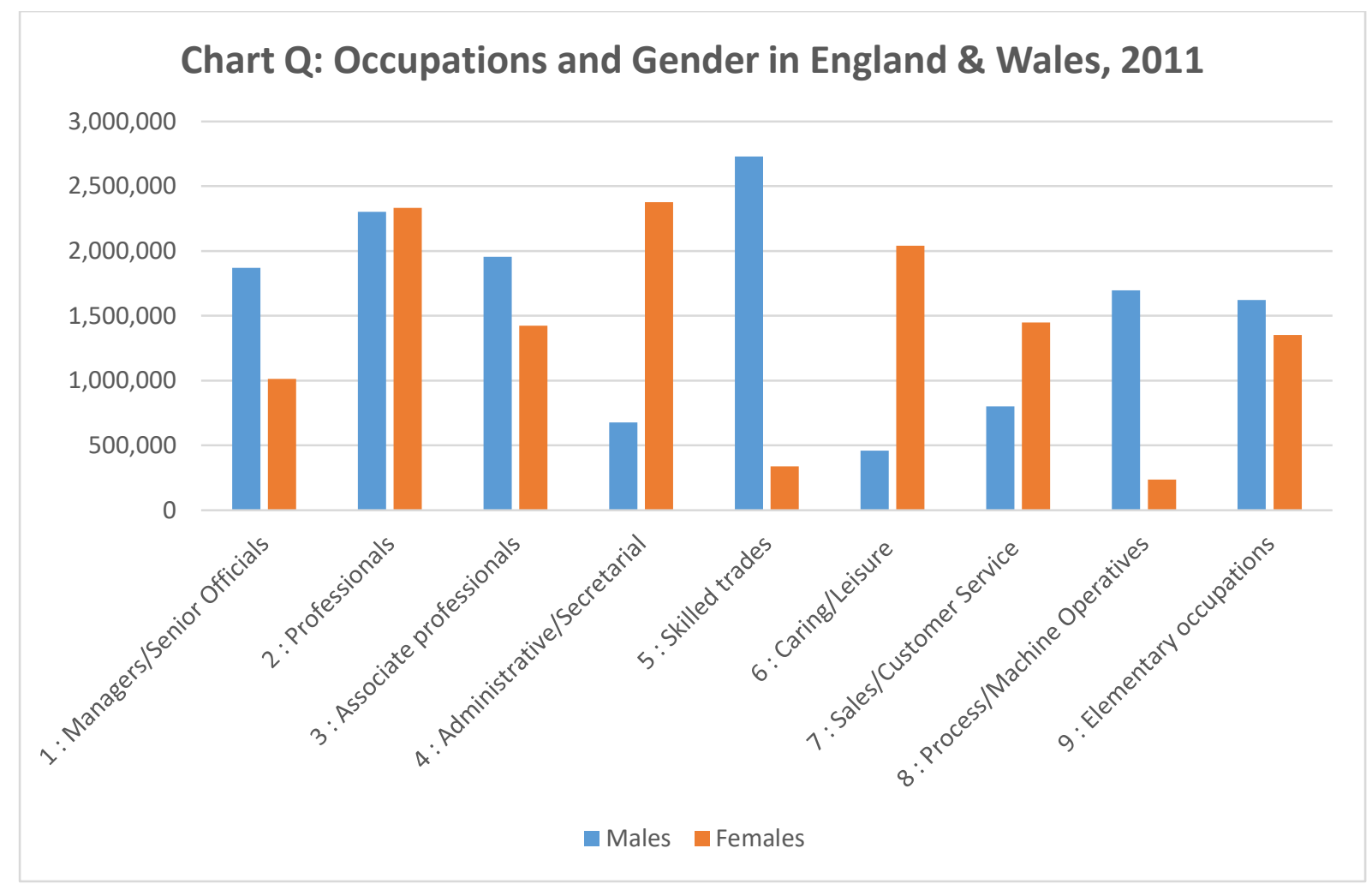

Skilled manual work continued to be overwhelmingly male in 2011 [see Chart Q]. Almost all skilled workers were male in the construction trades, as well as in metalworking. Indeed, the gendered characteristics of skilled work remained remarkably similar to the patterns seen in 1921 [see Chart R]. These have long historical antecedents and remain a powerful feature of contemporary British employment patterns. The continued strong involvement of craft workers in the day-to-day operation of the apprenticeship system has underpinned considerable pressure from the skilled workforce itself about the characteristics of apprentice intakes. Often boys are 'spoken for' by their fathers and uncles. This practice of restricting apprenticeships to the sons or male relatives of existing workers has maintained the maleness of such jobs and prevented the entry of female recruits. These traditions have produced strong expectations amongst craftsmen as to what an apprentice should look like - young and male - and also influenced managerial images about the boundaries between 'male' and 'female' work [see Penn, 1998]. 


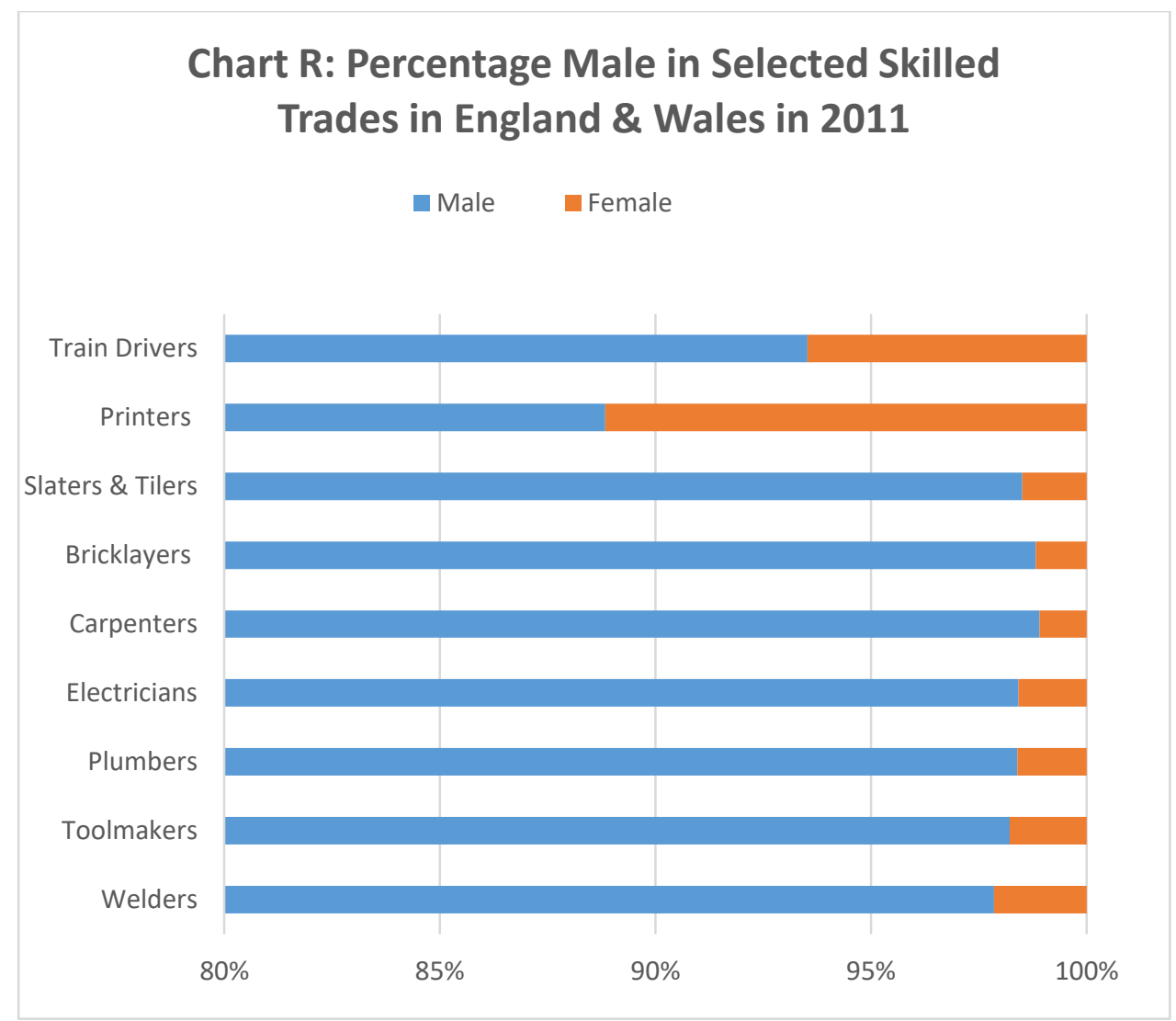

\section{Locality Variations in Employment in 2011}

In 1921 there were very powerful spatial concentrations of industrial employment. These were also associated with enormous variations in the proportion of women in employment. The patterns in the cotton towns of Lancashire and the woollen towns of Yorkshire were very different from those, for example, in South Wales where coal was king. Many sociologists believe these patterns are now no more than minor historical footnotes. Indeed, Marsh and Vogler (1995) argued strongly that employment patterns were becoming homogenized in the contemporary era. In their analysis of the six localities [Aberdeen, Coventry, Kirkcaldy, Northampton, Rochdale and Swindon] studied in the Social Change and Economic Life Initiative [SCELI] they claimed that in recent years 'the six areas lost much of their manufacturing distinctiveness and grew much more like the national average' [p51]. This economic convergence was, in their minds, based on two inter-related processes: a growing homogeneity of the structure of manufacturing in each locality and an increasing similarity in the size and composition of services.

It is beyond the scope of this analysis to provide an exhaustive test of these claims. However, a degree of caution is needed nonetheless. Chart $\mathrm{S}$ reveals that manufacturing still remains 
concentrated in specific localities as measured by the index of dissimilarity ${ }^{5}$. Barrow had almost two and a half times more employees in manufacturing in 2011 than the average for England and Wales. This is mainly the result of the continued centrality of shipbuilding [notably nuclear submarines] at the BAE Systems shipyard in the town. Blackburn, Merthyr, Stoke,Rochdale, Swindon and St Helens also had significantly larger proportions of people employed in manufacturing. There remained a significant relationship between manufacturing and place. It is likely that this is based upon earlier traditions and expectations that are rooted in the past. Evidence to support this claim was provided by qualitative interviews undertaken in 1990 as part of research funded by the Manpower Services Commission into the determinants of career choices made by pupils in their final year of education in Rochdale at the age of 16 [see Penn \& Scattergood, 1992]. Many of those interviewed reported that their choices were largely determined by parental advice and by the range of local options available to them. Subsequent research undertaken for the Department of Employment's Skills Task Force revealed that 'decisions made as early as the age of fourteen within the educational system either open up or foreclose future occupational possibilities' [Penn, 1999,] and that these decisions were based upon young people's and their parents' respective cognitive maps of the world of occupational possibilities. These are heavily sedimented within local industrial and occupational structures that have long histories. These issues merit further research.

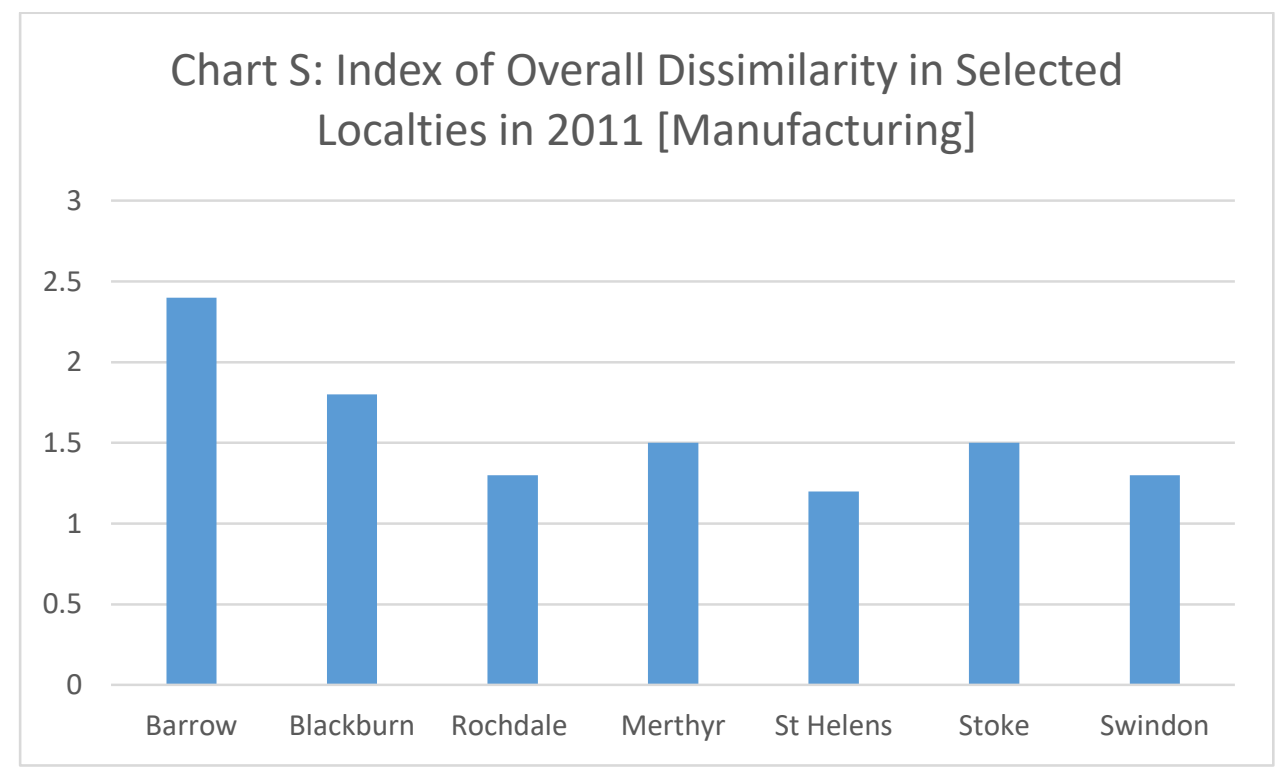

\footnotetext{
${ }^{5}$ An index of dissimilarity greater than 1 indicates a higher than average concentration of employment in that locality when compared to overall national patterns.
} 
Similar patterns can be seen in patterns of male employment in manufacturing. Males were much more likely to be employed in manufacturing in places with longstanding histories and traditions of such employment like Barrow, Blackburn and Rochdale in 2011. The continued salience of manufacturing employment particularly for males was explored in the earlier study of the career aspirations of 16 year olds in Rochdale in 1990 That research revealed that the desire for an apprenticeship was very strong amongst boys, particularly those with fathers employed in skilled manual occupations themselves. That research concluded that 'amongst manual working class families an apprenticeship for their son in a craft trade is still much prized' [see Penn \& Scattergood, 1992p85].

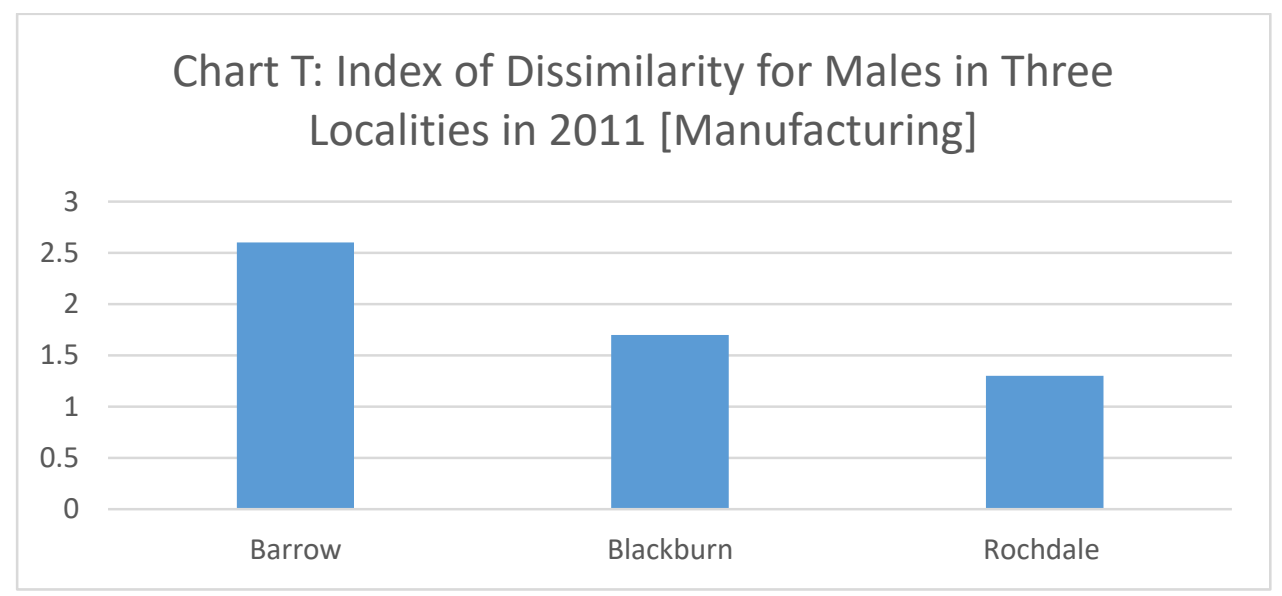

It is interesting to compare these patterns with the experience of Lancaster. In 1971, Lancaster remained a major centre for linoleum and related manufacture. [see Martin, 1973]. Three companies, each employing over 1000 employees, were the focal point of local employment at that time [see Urry \& Bagguley, 1990]. By 2011, all three had closed and Lancaster had two new universities and a range of new health facilities, including four hospitals. Out of a total workforce of 62,832 in the city there were 9173 employed in education and 10,112 in healthcare in 2011. From being a declining industrial city located in the traditional northern heartland of manufacturing, Lancaster has become a regional centre with a concentration of 'post-industrial' service sector jobs. Indeed, between 1981 and 2011 the population of Lancaster expanded by $16.7 \%$. Clearly, not every locality is locked into traditional patterns of employment. Again these topics merit further research. 


\section{Conclusions}

This paper has explored four main areas of employment change in England and Wales between 1921 and 2011. The first involved the broad contours of structural change in terms of industrial employment. There have been some dramatic shifts in patterns of employment. These include the decline of numbers working in manufacturing industry and agriculture as well as the almost complete demise of employment in coal mining. There has been a concomitant dramatic increase in numbers employed throughout the service sector, most notably in retailing, and wholesale, education, healthcare and professional and financial services. These changes provide strong evidence of the shift towards a post-industrial service economy. Yet, it should be overlooked that manufacturing remains a significant element in the overall economy.

There has also been a secular rise in the proportion of adult women who are economically active in England and Wales and a parallel fall in male economic activity rates. This is part of the wider 'gender revolution' in social life. However, it should be forgotten that, there were over 5 million women in employment in 1921. These were concentrated in textile and clothing manufacture, teaching, nursing and in domestic service. The almost complete disappearance of domestic servants since 1921 has been another major structural change to employment patterns ${ }^{6}$. Employment in transport, construction and utilities remained overwhelmingly male in 2011. Health, education and retail employment remained predominantly female. This was mirrored by powerful continuities in the gender characteristics of certain occupational groups. Teachers and nurses remained heavily female whilst skilled manual work continued to be overwhelmingly male. In 1921 there remained little evidence of the dilution of skilled trades during the First World War. Traditional patterns of male exclusion had been swiftly re-imposed at the end of the First World War. Skilled jobs remained almost exclusively male in 2011. These continued patterns of occupational segregation represent a remarkable degree of structural continuity.

There was pronounced spatial concentration to employment in 1921. Engineering, shipbuilding, coal, cotton and woollen manufacturing was heavily concentrated geographically at this time. These clusters often spread into wider industrial districts of inter-connected sets of businesses across related sectors. There were widely divergent gender patterns to these geographical concentrations. In the coal mining areas of South Wales and the North East of

\footnotetext{
${ }^{6}$ The demise of domestic service has led to a large increase in jobs as care assistants, cleaners and child minders. Most of these are also performed by women.
} 
England, very few adult women were employed in paid work. Conversely in the cotton towns of Lancashire, the majority of adult women were engaged in factory work.

These geographical clusters had not entirely disappeared by 2011. Certain localities continued to reveal disproportionate numbers employed in manufacturing. The male manual working class remains a strong element within such localities. This was particularly pronounced for male employment. The traditions of employment laid down in the late nineteenth and early twentieth centuries continue to affect employment patterns in specific places in the contemporary era.

It is clear that, despite a range of important changes to overall patterns of employment between 1921 and 2011 in terms of sectoral distribution, there also remains remained significant evidence of long-term structural stability. Skilled work remained almost exclusively male. Employment in health and education also remained predominantly female. Most sales assistants continue to be female whereas most employees in construction, utilities and transport continue to be male in 2011. As Di Lampedusa (1958) wrote in his classic novel about the dialectics of continuity and change in nineteenth century Sicily: 'If we want things to stay as they are, things will have to change'.

\section{Appendix A: Census Tables Used in the Analysis}

\section{1}

Census of England and Wales 1921: Occupation Tables (1924) London: HMSO.

Table 1; Occupations, by Sex, of Persons Aged 12 and Over, Distinguishing For Males in England and Wales Marital Condition, Industrial Status, and for Certain Occupations Those Working at Home [pp 2-21] 
Table 2: Occupations of Males Aged 12 Years and Over at Twelve Age Groups [pp22-35]

Table 4: Occupations of Females Aged 12 Years and Over Distinguishing Twelve Age Groups, Marital Condition, Industrial Status and, for Certain Occupations, Those Working at Home [54-109]

Census of England and Wales 1921: Industry Tables (1925) London: HMSO.

Table 1: Industries - Number of Persons Aged 12 and Over, Engaged in Each Industry, Showing the Occupational Distribution per Thousand Engaged in the Industry [pp4-11]

Table 2: Industries - Number of Persons Aged 12 and Over, Engaged in Each Industry, Distinguishing the Principal Occupations by Sex [12-207]

Table 4: Number of Males and Females Engaged in Each Industry (Condensed List) [pp356357]

2011

KS605EW-607EW Industry by Sex in England \& Wales

KS608EW-KS610EW Occupation by Gender in England \& Wales

DC6604EW Occupation (Full) by Industry in England \& Wales 
Appendix B: The Recoded Industrial Classifications Deployed in the Analysis

Recoding the 1921 Industrial Classification

\begin{tabular}{|l|l|}
\hline New Classification & $\begin{array}{l}\mathbf{1 9 2 1} \text { Industry Codes [Major Orders], (Minor } \\
\text { Orders) }\end{array}$ \\
\hline Agriculture \& Fishing & Fishing [I] \& Agriculture [II] \\
\hline Mining & Mining \& Quarrying [III] \\
\hline Manufacturing & $\begin{array}{l}\text { Bricks [IV], Chemicals [V], Metals [VI], Textiles } \\
\text { [VII], Leather [VIII], Clothing [IX], Food \& Drink [X], } \\
\text { Wood [XI], Paper [XII], Other Manufacturing [XIV] }\end{array}$ \\
\hline Construction & Building [XIII] \\
\hline Utilities & Gas, Water, Electricity [XV] \\
\hline Commerce & $\begin{array}{l}\text { Commerce \& Finance [XVII] minus Banking (684), } \\
\text { Insurance (685), Money Lending and Pawnbroking } \\
\text { (686), Other Finance (689) }\end{array}$ \\
\hline Transport & Transport \& Communication [XVI] \\
\hline Accommodation \& Food & $\begin{array}{l}\text { Personal Service [XXI]: Lodging (771), Restaurants } \\
\text { (772/773), Hotels (774/775) }\end{array}$ \\
\hline Financial Services & $\begin{array}{l}\text { Commerce \& Finance [XVII] restricted to Banking } \\
\text { (684), Insurance (685), Money Lending and } \\
\text { pawnbroking (686), Other Finance (689) }\end{array}$ \\
\hline Professional Services & $\begin{array}{l}\text { Professions [XIX] minus Medicine and Care of Sick } \\
\text { (732), Dentistry (733), Veterinary Surgery (734) }\end{array}$ \\
\hline Administration & $\begin{array}{l}\text { Public Administration and Defence [XVVIII] minus } \\
\text { Education (711/722) }\end{array}$ \\
\hline Education & $\begin{array}{l}\text { Public Administration and Defence [XVVIII]/(711): } \\
\text { Central Government, Education; Public } \\
\text { Administration and Defence [XVVIII]/(722): Local }\end{array}$ \\
\hline
\end{tabular}




\begin{tabular}{|l|l|}
\hline & $\begin{array}{l}\text { Government, Education; Professions [XIX]/(735) } \\
\text { Education }\end{array}$ \\
\hline Health & $\begin{array}{l}\text { Professions [XIX] Medicine and Care of Sick (732), } \\
\text { Dentistry (733), Veterinary Surgery (734) }\end{array}$ \\
\hline Other Services & $\begin{array}{l}\text { Entertainment \& Sport [XX], Personal Services } \\
\text { minus Lodging (771), Restaurants (772/773), } \\
\text { Hotels (774/775); Other [XXII] }\end{array}$ \\
\hline & \\
\hline
\end{tabular}

Recoding the 2011 Industrial Classification

\begin{tabular}{|l|l|}
\hline New Classification & 2011 Industry Codes \\
\hline Agriculture \& Fishing & Agriculture, Forestry \& Fishing [A] \\
\hline Mining & Mining \& Quarrying [B] \\
\hline Manufacturing & Manufacturing [C] \\
\hline Utilities & $\begin{array}{l}\text { Electricity, Gas, Steam and Air } \\
\text { Conditioning Supply [D], Water [E] }\end{array}$ \\
\hline Construction & Construction [F] \\
\hline Retail and Wholesale & Retail and Wholesale [G] \\
\hline Transport & Transport \& Storage [H] \\
\hline Hospitality & Accommodation \& Food Service [I] \\
\hline Financial Services & $\begin{array}{l}\text { Information \& Communication } \\
{[\mathrm{J}] \text { Financial \& Insurance [K] }}\end{array}$ \\
\hline Professional Services & $\begin{array}{l}\text { Real Estate [L], Professional, } \\
\text { Scientific and Technical [M] }\end{array}$ \\
\hline Administration & $\begin{array}{l}\text { Administrative \& Support Services } \\
{[\mathrm{N}], \text { Public Administration \& Defence }} \\
{[\mathrm{O}]}\end{array}$ \\
\hline Education & Education [P] \\
\hline Health & Human Health \& Social Work [Q] \\
\hline Other Services & Other Services [R,S,T,U] \\
\hline
\end{tabular}




\section{References}

Aldcroft, D. (1970) The Inter-War Economy: Britain, 1919-1939 New York: Columbia University Press.

Akehurst, G. \& Alexander, N. (1996) [eds] Retail Employment London: Frank Cass.

Arnot, M., David, M. and Weiner, G. (1999) Closing the Gender Gap: Postwar Education and Social Change Oxford: Polity Press.

Ashworth, W. (1986) The History of the British Coal Industry Vol 5, 1946-82: The Nationalized Industry Oxford: Oxford University Press.

Banks, J. (1978) 'Occupation Statistics in the Nineteenth Century' in R. Lawton [ed] The Census and Social Structure London: Frank Cass.

Bell, D. (1974) The Coming of Post Industrial Society London: Basic Books.

Bellamy, J. (1978) 'Occupation Statistics in the Nineteenth Century' in R. Lawton [ed] The Census and Social Structure London: Frank Cass.

Berridge, D., Penn, R. \& Ganjali, M. (2009) 'Changing Attitudes to Gender Roles: a Longitudinal Analysis of Ordinal Response Data from the British Household Panel Study' International Sociology, 24, 3, 346-367

Beynon, H. (1985)[ed] Digging Deeper: Issues in the Miner's Strike London: Verso.

Blackburn, R., Jarman, J. and Racko, G. (2014) 'Occupational Segregation: Its vertical and Horizontal Dimensions' in G. Razzu [ed] Gender Inequalities in the Labour Market in the $U K$ Oxford: Oxford University Press.

Blau, F,. Brinton, M. \& Grusky, D. (2006) The Declining Significance of Gender? [Eds] New York: Russell Sage Foundation.

Bolton, P. (2012) Education: Historical Statistics SN/SG/4252. House of Commons Library. 
Bonacich, E. \& Wilson, J. (2008) Getting the Goods: Ports, Labor and the Logistics Revolution Ithaca, NY: Cornell University Press.

Braudel, F. (1949) La Méditerranée et le monde méditerranéen à l'époque de Philippe II: 3 vols [The Mediterranean and the Mediterranean World in the Age of Philip II: 3 vols] Paris: Livre de Poche.

Braybon, G. (1980) Women Workers in the First World War London: Routledge.

Cattell, J. \& Falconer, K. (1995). Swindon: the Legacy of a Railway Town. London: HMSO.

Census of England and Wales, 1921 (1923) Classification of Occupations and Industries London: HMSO.Census of England and Wales 1921: Occupation Tables (1924) London: HMSO.

Census of England and Wales 1921: Industry Tables (1925) London: HMSO.

Census of England and Wales, 1921 (1927a) A Dictionary of Occupational Terms: Based on the Classification of Occupations used in the Census of Population, 1921 London: HMSO

Census of England and Wales, 1921. (1927b) General Report with Appendices London: HMSO.Church, R. (1986) The History of the British Coal Industry, Vol 3, 1830-1913 Oxford: Clarendon Press.

Clarke, P. (1996), Hope and Glory: Britain 1900-1990, London: Penguin.

Clavin, P. (2000), The Great Depression in Europe 1929-1939, New York: St. Martin's Press.

Coats, R. 'British Empire Statistical Conference at London, Quarterly Publications of the American Statistical Association 17, 130, 226-228

Cole, G. (1923a) Trade Unionism and Munitions Oxford: Clarendon Press.

Cole, G. (1923b) Workshop Organization Oxford: Clarendon Press.

Committee on British Empire Statistics (1921) Report and Resolutions Adopted Cmd. 648

Kew: National archives BT 70/2/S594/21.

Connolly, S. \& Gregory, M. (2007) 'Women and Work since 1970' in N. Crafts, I. Gazeley and A. Newell [eds] Work and Pay in Twentieth Century Britain Oxford: Oxford University Press.

Cotter, D., Hermsen, J. \& Vanneman, R. 'The End of the Gender Revolution? Gender Role Attitudes from 1977 to 2008' American Journal of Sociology, 116, 4, 1-31.

Crompton, R. (1999) [ed] Restructuring Gender Relations and Employment: The Decline of the Male Breadwinner Oxford: Oxford University Press. 
Danford, A., Richardson, M., Stewart, P., Tailby, S. \& Upchurch, M. (2005) Partnership and the High Performance Workplace: Work and Employment Relations in the Aerospace Industry London: Palgrave Macmillan.

Davis, R. \& Cousins, J. (1975) 'The New Working Class and the Old' in M.Bulmer [ed] Working Class Images of Society London: Routledge.

Dex, S. Ward, K. \& Joshi, H. 'Changes in Women's Occupational Mobility over 25 Years' in Scott, J., Dex, S. \& Joshi, H. (2008) [eds] Women and Employment: Changing Lives and New Challenges Cheltenham: Edward Elgar.

Duby, G. (1973) Le Dimanche de Bouvines [Sunday at Bouvines] Paris: Gallimard.

Evans, H. (1978) Vickers: Against the Odds 1956-1977 London: Hodder \& Stoughton. Evans, M. (2014) Sage Handbook of Feminist Theory London: Sage.

Farnie, J. \& Sparks, L. (2014) Logistics and Retail Management London: Kogan Page

Fingleton, E. (1999) In Praise of Hard Industries: Why Manufacturing, Not the New Economy is the Key to Future Prosperity London: Orion Press.

Freeman, C. (1988) 'Evolution, Technology and Institutions: A Wider Framework for Economic Analysis' in G. Dosi, C.Freeman, R.Nelson, G. Silverderg and L. Soete (eds) Technical Change and Economic Theory London: Pinter.

Fuchs, V. (1968) The Service Economy New York: Basic Books.

Goldthorpe, J., Lockwood, D. Bechhofer, F. \& Platt, J. (1969) The Affluent Worker in the Class Structure Cambridge: Cambridge University Press.

Grayzel, S. (1999) Women's Identities at War Chapel Hill, NC: University of North Carolina Press.

Habermas, J. (1976) Legitimation Crisis London: Henemann.

Hoggart, R. (1959) The Uses of Literacy Harmondsworth: Penguin.

Jarman, J., Blackburn, R. \& Racko, G. (2012)The Dimensions of Occupational Gender Segregation in Industrial Countries' Sociology, 46,6, 1003-1019.

Jones, B. (1997) Forcing the Factory of the Future Cambridge: Cambridge University Press.

Kristensen, P. \& Lilja, K. (2012) [eds] Nordic Capitalisms and Globalization: New Forms of Economic Organization and Welfare Institutions Oxford: Oxford University Press.

Lampedusa, di, G. (1958) Il Gattopardo [The Leopard] Milano: Feltrinelli. 
Lesterhaeghe, R. \& Neels, K. (2002) 'From the First to the Second Demographic Transition: An Interpretation of the Spatial Continuity of Demographic Innovation' European Journal of Population, 18, 4, 225-260.

Lethbridge, L. (2013) Servants: A Downstairs View of Twentieth Century Britain London: Bloomsbury.

Lewis, J. (1984) Women in England 1870-1950: Sexual Divisions and Social Change London: Harvester.

Lockwood, D. (1960) 'The "New Working Class"' European Journal of Sociology,1, 2, 248259.

Lockwood, D. (1966) 'Sources of Variation in Working Class Images of Society', Sociological Review, 14, 3, 249-267.

Marsh, C. \& Vogler, C. (1995) 'Economic Convergence: A Tale of Six Cities' in D. Gallie, C. Marsh \& C. Vogler [eds] Social Change and the Experience of Unemployment Oxford: Oxford University Press.

Martin, R. (1973) Redundancy and Paternalist Capitalism London: Allen \& Unwin.

McAllister, F. \& Clarke, L. (1998) Choosing Childlessness London: Family Policy Studies Centre.

McGill, J. (1973) Crisis on the Clyde Glasgow: Harper Collins.

More, C. (1980) Skill and the English Working Class, 1870-1914 London: Croom Helm.

Newell, A. (2007) 'Structural Change' in N. Crafts, I.Gazeley \& A. Newell [eds] Work and Pay in Twentieth Century Britain Oxford: Oxford University Press.

Nissel, M. (1987) People Count: A History of the General Register Office London: HMSO.

Office of National Statistics [ONS] (2009) UK Standard Industrial Classification of Economic Activities, 2007 (SIC 2007) London: Palgrave Macmillan.

Office of National Statistics [ONS] (2010a) Standard Occupational Classification 2010 Volume 1: Structure and Descriptions of Unit Groups London: Palgrave Macmillan.

Office of National Statistics [ONS] (2010b) Standard Occupational Classification 2010 Volume 2: The Coding Index London: Palgrave Macmillan.

Office for National Statistics (2016)] Participation Rates in Higher Education 2005-2015 SFR45/2016 Department of Education

Oxford Economics (2011) London's Competitive Place in the UK and Global Economics City of London Corporation: Economic Development Office.

[http://www.cityoflondon.gov.uk/economicresearch] 
Penn, R. (1985) Skilled Workers in the Class Structure Cambridge: Cambridge University Press [New edition, 2010].

Penn, R. (1997) 'Social Exclusion and Modern Apprenticeships' Journal of Vocational Education \& Training, 50:2, 259-275.

Penn, R. (1999) 'The Dynamics of Decision-Making in the Sphere of Skills' Formation', Sociology, 33, 3,325-340.

Penn, R. (2014) 'The Sociological Analysis of Historical Census Data Using Graphical Representations: An Illustration from the 1921 Census of England and Wales', Sage Research Methods Cases, 2014, London: Sage

Penn, R. \& Scattergood, H. (1992) 'Ethnicity and Career Aspirations in Contemporary Britain’ New Community, 19, 1, October, 75-98.

Purcell, K. \& Elias, P. (2008) 'Achieving Equality in the Knowledge Economy' in Scott, J., Dex, S. \& Joshi, H. (2008) [eds] Women and Employment: Changing Lives and New Challenges Cheltenham: Edward Elgar.

Razzu, G. \& Singleton, C. (2018) 'Segregation and Gender Gaps in the United Kingdom's Great Recession and Recovery’ Feminist Economics, 1003-1019.

Rees, P. (1997) 'The Second Demographic Transition: What Does it Mean for the Future of Europe's Population?' Environment \& Planning, A, 29, 381-390.

Reid, A. (2010) The Tide of Democracy: Shipyard Workers and Social Relations in Britain, 1870-1950 Manchester: Manchester University Press.

Roberts, E. (1988) Women's Work1840-1914 London: Macmillan.

Ritzer, G. (1993) The McDonaldization of Society: an Investigation into the Changing Character of Contemporary Social Life Newbury Park, Ca: Pine Forge Press.

Royle, E. Modern Britain: A Social History 1750-1997 London: Arnold. 
Savage, M. (1987) The Dynamics of Working Class Politics Cambridge: Cambridge University Press.

Schulman, M., Leiter, J. \& Zingraff, R. (1991) [eds] Textiles in the Modern World Ithaca, NY: Cornell University Press.

Scott, J., Dex, S. \& Joshi, H. (2008) [eds] Women and Employment: Changing Lives and New Challenges Cheltenham: Edward Elgar.

Seccombe, W. (1986) 'Patriarchy Stabilized: The Construction of the Male Breadwinner Wage Norm in Nineteenth Century Britain' Social History, 11, 1, 53-76.

Szreter, S. (1984) 'The Genesis of the Registrar-General's Social Classification of Occupations' British Journal of Sociology, 35, 4, 522-546.

Touraine, A. (1969) The Post-Industrial Society New York: Random House

Trebilcock, C. (1977) The Vickers Brothers: Armaments and Enterprise 1854-1914. London: Europa

Universities UK, (2015) Patterns and Trends in UK Higher Education, 2015 London: ISBN 978-1-84036-351-7.

Urry, J., \& Bagguley, P. (1990) [eds] Restructuring Place, Class and Gender London: Sage.

Van de Kaa, D. 'Europe’s Second Demographic Transition' Population Bulletin, 42, 1, 1-59.

Walby, S. (1986) Patriarchy at Work: Patriarchal and Capitalist Relations in Employment. Oxford: Polity Press.

Walton, J. (1992) Fish and Chips and the British Working Class Leicester: Leicester University Press.

Walton, J. (2000) The British Seaside: Holidays and Resorts in the Twentieth Century Manchester: Manchester University Press.

Walvin, J. (1994) The People's Game: The History of Football Revisited Edinburgh: Mainstream Publishing.

Watkins, E. (2001) On the Pill: A Social History of Oral Contraceptives Baltimore, MD: Johns Hopkins University Press.

Webb, J. (2008) 'Gender and the Post-Industrial Shift' in Scott, J., Dex, S. \& Joshi, H. [eds] Women and Employment: Changing Lives and New Challenges Cheltenham: Edward Elgar.

Whipp, R. (1990) Patterns of Labour: Social Change in the Pottery Industry London: Routledge.

Williams, R. (1958) Culture and Society London: Chatto \& Windus. 
Willmott, P. \& Young, M. (1957) Family and Kinship in East London London: Routledge and Kegan Paul

Total Word Count: 8627 